\title{
Response of Oxidative Stress Variables, Proteins, and Chlorophyll in Three Plant Species Caused by Moderate Soil Pollution with Toxic Elements
}

\author{
Adinuţa Păun ${ }^{1}$, Aurora Neagoe ${ }^{2 *}$, Mihaela Păun³ ${ }^{3}$ Ion Baciu', Virgil Iordache² \\ 'Department of Organic Chemistry, Biochemistry and Catalysis, Faculty of Chemistry, University of Bucharest, \\ 90-92 Panduri Road, District 5, Bucharest, Romania \\ ${ }^{2}$ Research Centre for Ecological Services (CESEC), Faculty of Biology, University of Bucharest, \\ 91-95 Splaiul Independentei Street, District 5, Bucharest, Romania \\ ${ }^{3}$ Department of Statistics, University of Glasgow, G12 8QQ Glasgow, Scotland, UK
}

Received: 12 May 2014

Accepted: 23 September 2014

\begin{abstract}
The ecotoxicological effects in the field can be directly assessed by measuring the concentration of the pollutant in soil or plant samples, and also by measuring response variables such as biochemical ones. However, there are few such studies integrating data on pollutants and plant biochemical variables and there is a knowledge gap about how dominant species in various ecological contexts respond in all their plant parts to heavy metal stress by changing biochemical variables. In this context, the objective of the research reported here is to describe how select biochemical variables varied in three plant parts of three plant species sampled from two areas with different levels of pollution. It was also of interest to identify to what extent they could be used in the non-destructive routine monitoring of pollution in industrial areas. We found a systematic decrease of chlorophylls and carotenoids in the aboveground parts of all species, and an increase of protein concentrations in all species and plant parts coupled with a decrease of superoxide dismutase and peroxidase activity. Although these patterns were correlated with a decrease of toxic element concentrations, both as pseudo-total and available forms in all plant parts, we cannot conclude that only a change in toxic elements pollution led to the observed patterns, because P nutrition also differed between plants. A further key direction of research is to clarify how the available major nutrients $(\mathrm{N}, \mathrm{P})$ modulate bioaccumulation of toxic elements and what effects they might have on biochemical variables of plants, in particular on oxidative stress.
\end{abstract}

Keywords: Taraxacum officinale, Lotus corniculatus, Plantago major, polymetallic pollution, oxidative stress

\section{Introduction}

Exposure of plants to metal concentration in excess could cause a number of toxic symptoms, for instance growth retardation, inhibition of photosynthesis, and induc-

*e-mail: auroradaniela.neagoe@g.unibuc.ro tion or inhibition of enzymes that generate the oxidative stress [1-4]. When plants are subjected to stress caused by the existence of one or several pollutants, cell membranes are the first to be affected, leading to an increase of their permeability [2]. A variety of reactive oxygen species (ROS) are simultaneously induced, such as superoxyde $\left(\mathrm{O}_{2}^{-}\right)$, hydroxyl radical $\left(\mathrm{OH}^{*}\right)$, hydrogen peroxyde $\left(\mathrm{H}_{2} \mathrm{O}_{2}\right)$, 
peroxides and their decomposition products. Another known ROS is atmospheric ozone $\left(\mathrm{O}_{3}\right)$, which is capable of producing alterations characteristic of hypersensitivity in plants [3]. Therefore, the free radicals of oxygen may appear in plants either as a consequence of external stress factors (such as exposure to atmospheric pollution or any other type of pollution), or as a result of chemical reactions. These reactions take place in plants after treatment with reagents capable of producing free radicals, or during some physiological processes such as photosynthesis. In fact, all organisms are exposed to various stress factors and they generally have the ability to adapt to unfavorable conditions. This adaptation can be possible:

1) By inducing an osmotic adjustment

2) By producing antioxidant compounds such as vitamins $\mathrm{E}$ and $\mathrm{C}$, uric acid, and beta carotene

3) By induction or inhibition of antioxidant enzymes (superoxide dismutase - SOD, catalases - CAT, and peroxidases - POD)

4) By induction or inhibition of some metal chelation agents (such as transferrin, lactoferrin, and ceruloplas$\min )$

These agents function as an antioxidant system by binding the potentially harmful metallic ions [4]. Ions of elements such as $\mathrm{Fe}, \mathrm{Cu}, \mathrm{Zn}, \mathrm{Co}$, or $\mathrm{Ni}$ are essential micronutrients that are involved in functional activities of a large number of proteins whose role is to sustain the growth and development of living organisms. On the other hand, plants also can be exposed to highly toxic ions such as $\mathrm{Cd}, \mathrm{Pb}$, $\mathrm{Hg}$, and other metals that are generally considered nonessential [5]. However, micronutrients may also become toxic if they accumulate higher concentrations in the organelles of plant cells. For many elements, the concentration ranges of deficiency, optimal supply, and toxicity are very close. Moreover, the phytotoxic effect occurs differentially on the toxic metals uptake in different plant species, being strongly influenced by the composition of different soil components such as carbonates, hydroxides, organic matter, and silica. It is also important to note that the determination of total or pseudo-total concentrations of toxic elements does not provide enough useful information about the risk of their bioavailability, their ability to remobilize, their toxicity in the environment, and about the chemical form in which they are available. That is why it is very often advisable to evaluate the speciation of elements with toxic potential, thus allowing their bioavailability assessment [6].

In order to get an idea of the ecotoxicological effects on plants in the field, not only is it important to measure the concentration of different forms of the pollutant in soil or plant samples, but also to measure response variables such as biochemical ones [7]. However, there are few such studies integrating data on pollutants and plant biochemical variables in the field. Dazy et al. [8] reported the existence of alterations in biochemical variables (oxidative stress, protein concentrations and photosynthetic pigments) in plant communities, but working only on leaves on strong gradients of soil heavy metal pollution. Al Sayegh Petkovšek [9] also worked only on spruce needles and demonstrated that as the concentrations of pollutants decrease, tree vitality increases. This vitality was correlated with a higher concentration of total $(a+b)$ chlorophyll and a stronger defense capability that was demonstrated by the high concentration of ascorbic acid. There is insufficient information about how dominant species in various ecological contexts respond in all their plant parts to metal stress by changing biochemical variables. Do these changes have the same pattern in all plant parts, are these changes identifiable only on strong pollution gradients, or on small pollution gradients as well? Such questions are important both from the point of view of basic science and for the design of monitoring programs.

In this context, the objective of the research reported here is to describe how select biochemical variables varied in three plant parts of three plant species sampled from two areas with different levels of pollution. We believe that an early detection of plant metabolic changes may help to assess whether they can be used as bioindicators of metals in soil. Thus, the results of this study will allow researchers to focus on establishing and implementing a coherent program of remediating metal-polluted industrial areas, a program supported by a permanent monitoring of oxidative stress variables. We were interested in finding out the extent to which the patterns of biochemical variables (as result of pollution) differ depending on the plant species and the plant parts analyzed.

\section{Materials and Methods}

\section{Plant Selection and Polluted Area Description}

Three species of plants from spontaneous flora have been studied in a polluted industrial area. Two of them were herbaceous plants, the dandelion (Taraxacum officinale) and the plantain (Plantago major). The third one, the clover, was leguminous (Lotus corniculatus). These species were chosen because they have a large spread in the studied area, allowing their harvesting on soils with different degrees of pollution in order to perform a comparative analysis to highlight changes that may serve as biomarkers to assess the impact anthropic area. On the other hand, specialized literature has often stated that these species have a relatively high potential of tolerance to metal pollution $[10,11]$. Both soil and plant samples were sampled from two different areas located near the pollution source: an area located at approximately $250 \mathrm{~m}$ away, coded with A, and an area situated on the same side as the pollution source, $2 \mathrm{~km}$ from it, in a supposedly unpolluted meadow, coded with $\mathrm{B}$. The pollution source was the largest aluminum manufacturing company in Central and Eastern Europe (except Russia), which is located in Romania 120 kilometers west of Bucharest (geographical coordinates: $44^{\circ} 26^{\prime} 13^{\prime \prime} \mathrm{N}, 24^{\circ} 22^{\prime} 12^{\prime \prime}$ E in WGS84 system) and has polluted an area of more than 100 ha. The manufacturing of aluminium started in 1966, with a capacity of 55,000 tons annually. The current production capacity of the S.C.ALRO S.A. plant is of 260,000 tons annually. This ferrous metallurgical enterprise (primarily aluminium and 
Table 1. Physicochemical characterization of soils from investigated area.

\begin{tabular}{|c|c|c|c|c|c|c|c|c|}
\hline & Variable & $\mathrm{pH}$ & $\mathrm{EC}$ & $\mathrm{H}$ & $\mathrm{N}-\mathrm{NH}_{4}^{+}$ & $\mathrm{N}-\mathrm{NO}_{3}^{-}$ & $\mathrm{N}-\mathrm{NO}_{2}^{-}$ & $\mathrm{P}-\mathrm{PO}_{4}^{3-}$ \\
\hline & unit & $\mathrm{H}_{2} \mathrm{O}$ & $\mu \mathrm{S} / \mathrm{cm}$ & $\%$ & \multicolumn{4}{|c|}{$\mu \mathrm{g} / \mathrm{g}$ d.w. } \\
\hline A1 & $\overline{\mathrm{x}}$ & 5.84 & 35.33 & 14.38 & 6.156 & 3.587 & BDL & 30.16 \\
\hline$(\mathrm{n}=6)$ & S & 0.06 & 8.164 & 1.920 & 0.229 & 1.228 & - & 13.08 \\
\hline $\mathrm{A} 2$ & $\overline{\mathrm{x}}$ & 6.63 & 54.66 & 15.94 & 6.826 & 4.661 & BDL & 50.58 \\
\hline$(n=6)$ & $\mathrm{S}$ & 0.27 & 19.32 & 5.48 & 0.244 & 3.01 & - & 30.40 \\
\hline B1 & $\overline{\mathrm{x}}$ & 5.27 & 16.74 & 9.678 & 9.908 & 36.32 & 0.560 & 53.27 \\
\hline$(\mathrm{n}=50)$ & $\mathrm{S}$ & 0.34 & 9.448 & 1.023 & 1.807 & 22.86 & 0.405 & 26.94 \\
\hline
\end{tabular}

$\mathrm{n}$ - number of replicates, BDL - below detection limit Detection limit $\left(<2 \mu \mathrm{g} / \mathrm{NO}_{2}-\mathrm{N} / \mathrm{l}\right)$

Table 2. Pseudo-total of elements content.

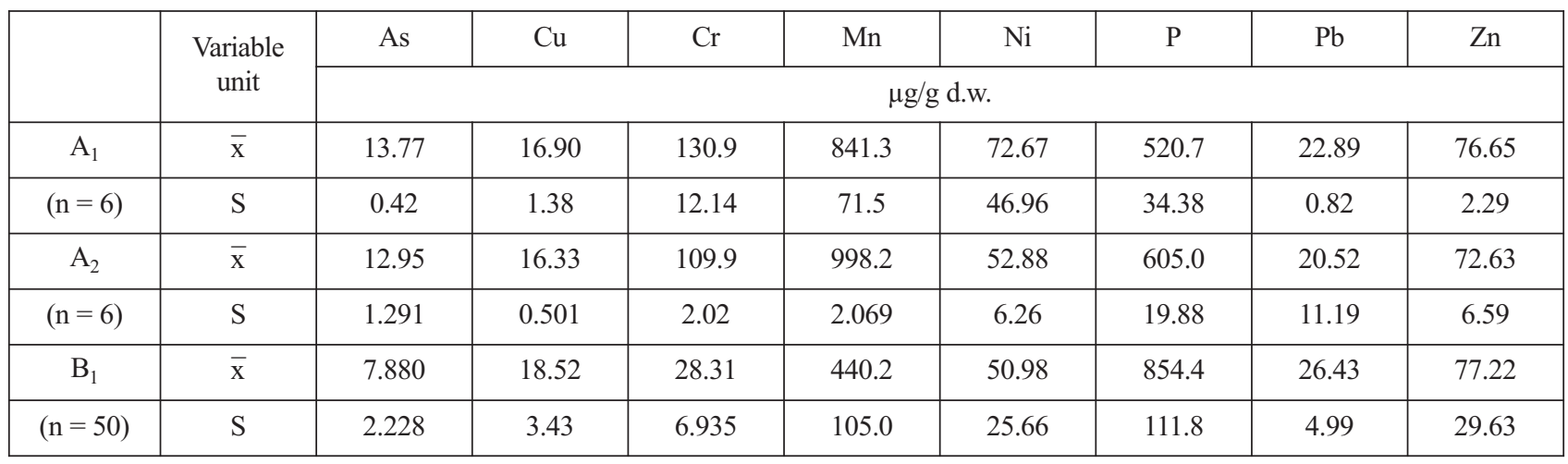

$\mathrm{n}$ - number of replicates

Table 3. Element content of bioavailable fraction.

\begin{tabular}{|c|c|c|c|c|c|c|c|c|c|}
\hline & \multirow{2}{*}{$\begin{array}{c}\text { Variable } \\
\text { unit }\end{array}$} & As & $\mathrm{Cr}$ & $\mathrm{Cu}$ & $\mathrm{Mn}$ & $\mathrm{Ni}$ & $\mathrm{P}$ & $\mathrm{Pb}$ & $\mathrm{Zn}$ \\
\hline & & \multicolumn{8}{|c|}{$\mu \mathrm{g} / \mathrm{g}$ d.w. } \\
\hline $\mathrm{A}_{1}$ & $\overline{\mathrm{x}}$ & 0.022 & 0.946 & 2.449 & 22.18 & 0.852 & 6.509 & 0.104 & 1.683 \\
\hline$(n=6)$ & $\mathrm{S}$ & 0.003 & 0.166 & 0.158 & 0.117 & 0.117 & 0.430 & 0.029 & 0.360 \\
\hline $\mathrm{A}_{2}$ & $\overline{\mathrm{x}}$ & 0.016 & 0.752 & 1.690 & 18.37 & 0.689 & 9.980 & 0.077 & 1.820 \\
\hline$(n=6)$ & $\mathrm{S}$ & 0.000 & 0.070 & 0.138 & 1.987 & 0.075 & 0.777 & 0.003 & 0.171 \\
\hline $\mathrm{B}_{1}$ & $\overline{\mathrm{x}}$ & 0.010 & 0.415 & 2.630 & 13.71 & 0.514 & 10.68 & 0.047 & 1.440 \\
\hline$(\mathrm{n}=6)$ & S & 0.002 & 0.036 & 0.579 & 3.018 & 0.113 & 1.397 & 0.019 & 0.264 \\
\hline
\end{tabular}

$\mathrm{n}$ - number of replicates

alloys) releases waste gases from central heating, sulphur dioxide $\left(\mathrm{SO}_{2}\right)$, particulates, petroleum coke, etc. from the anode section, and aerosols, carbon monoxide (CO), sulphur dioxide $\left(\mathrm{SO}_{2}\right)$, and particulate matter containing fluorine from the electrolysis sections. Moreover, an average volume of 700 cubic meters/day of sewage wastes are discharged into the sewage system of Slatina city [12]. Therefore, as a direct consequence of continuing the above-mentioned industrial activities, it was found that the fluoride and metals pollution has affected the animal and human population. Fluorides such as $\mathrm{NaF}$ and $\mathrm{AlF}_{3}$ are obtained through electrolysis of the cryolite-alumina fusion with coal anode and aluminum cathode melted at temperatures of $950-970^{\circ} \mathrm{C}$. Also, the metals resulted from the activities of obtaining and processing aluminum have polluted the crops, pastures, and spontaneous vegetation in the vicinity of the aluminum plant [13], also contaminating the surface and underground waters [14].

\section{Soil Characterization and Sampling}

The soil from this polluted area belongs to the podzoluvisols class of soils according to the FAO/UNESCO classification [15], presenting a high quantity of clay, calcareous concretions and a 5 to $8 \mathrm{~cm}$ layer of cemented organic matter on the surface [16]. Also, the soil nearby the 
Table 4. Soil variables and element content from the three plant rhizospheres.

\begin{tabular}{|c|c|c|c|c|c|c|c|}
\hline \multirow{2}{*}{$\begin{array}{c}\text { Soil } \\
\text { variable }\end{array}$} & \multirow{2}{*}{ Units } & \multicolumn{3}{|c|}{ Area (A) } & \multicolumn{3}{|c|}{ Area (B) } \\
\hline & & Dandelion & Clover & Plantain & Dandelion & Clover & Plantain \\
\hline $\mathrm{pH}$ & & $5.24 \pm 0.154$ & $7.60 \pm 0.193$ & $7.50 \pm 0.186$ & $5.03 \pm 0.100$ & $6.05 \pm 0.127$ & $5.74 \pm 0.106$ \\
\hline $\mathrm{EC}$ & $\mu \mathrm{S} \cdot \mathrm{cm}^{-1}$ & $30.71 \pm 3.302$ & $102.5 \pm 15.11$ & $125.9 \pm 14.18$ & $92.00 \pm 13.12$ & $110.7 \pm 22.23$ & $102.2 \pm 13.45$ \\
\hline $\mathrm{H}$ & $\%$ & $16.23 \pm 6.106$ & $13.37 \pm 3.458$ & $12.12 \pm 3.821$ & $4.424 \pm 0.679$ & $7.877 \pm 1.770$ & $7.223 \pm 0.803$ \\
\hline $\mathrm{N}-\mathrm{NH}_{4}^{+}$ & \multirow{20}{*}{$\mu \mathrm{g} \cdot \mathrm{g}^{-1}$ d.w. } & $1.360 \pm 0.762$ & $1.674 \pm 0.489$ & $1.931 \pm 0.413$ & $10.70 \pm 5.802$ & $12.05 \pm 4.373$ & $8.711 \pm 2.014$ \\
\hline $\mathrm{N}-\mathrm{NO}_{3}^{-}$ & & $10.56 \pm 5.462$ & $9.480 \pm 8.071$ & $5.702 \pm 6.452$ & $48.28 \pm 36.19$ & $97.34 \pm 79.50$ & $77.02 \pm 41.79$ \\
\hline $\mathrm{N}^{-\mathrm{NO}_{2}^{-}}$ & & $0.110 \pm 0.039$ & $0.295 \pm 0.095$ & $0.274 \pm 0.076$ & $0.439 \pm 0.133$ & $0.789 \pm 0.339$ & $0.645 \pm 0.252$ \\
\hline $\mathrm{P}_{-} \mathrm{PO}_{4}^{3-}$ & & $14.75 \pm 4.679$ & $18.77 \pm 3.984$ & $16.42 \pm 8.680$ & $18.39 \pm 2.407$ & $35.53 \pm 5.820$ & $22.54 \pm 2.027$ \\
\hline $\mathrm{As}^{\mathrm{a}}$ & & $\underline{8.652} \pm 1.850$ & $\underline{8.683} \pm 1.533$ & $\underline{10.13} \pm 1.548$ & $4.387 \pm 0.478$ & $4.278 \pm 0.779$ & $3.931 \pm 0.111$ \\
\hline$A s^{b}$ & & $0.010 \pm 0.004$ & $0.007 \pm 0.002$ & $0.008 \pm 0.001$ & $0.008 \pm 0.002$ & $0.004 \pm 0.001$ & $0.003 \pm 0.001$ \\
\hline $\mathrm{Cr}^{\mathrm{a}}$ & & $\underline{95.88} \pm 6.238$ & $\underline{102.7} \pm 9.410$ & $\underline{119.5} \pm 8.701$ & $25.83 \pm 3.035$ & $22.66 \pm 2.992$ & $24.68 \pm 4.507$ \\
\hline $\mathrm{Cr}^{\mathrm{b}}$ & & $0.798 \pm 0.112$ & $0.538 \pm 0.050$ & $0.571 \pm 0.114$ & $0.269 \pm 0.036$ & $0.175 \pm 0.026$ & $0.213 \pm 0.109$ \\
\hline $\mathrm{Cu}^{\mathrm{a}}$ & & $30.29 \pm 7.824$ & $26.30 \pm 5.893$ & $25.26 \pm 5.186$ & $27.52 \pm 8.766$ & $27.44 \pm 5.675$ & $29.52 \pm 3.487$ \\
\hline $\mathrm{Cu}^{\mathrm{b}}$ & & $2.098 \pm 0.605$ & $1.161 \pm 0.246$ & $1.058 \pm 0.210$ & $1.777 \pm 0.479$ & $1.200 \pm 0.294$ & $1.427 \pm 0.203$ \\
\hline $\mathrm{Mn}^{\mathrm{a}}$ & & $\underline{851.3} \pm 147.1$ & $\underline{655.7} \pm 123.9$ & $\underline{735.6} \pm 131.4$ & $352.8 \pm 64.29$ & $323.9 \pm 44.01$ & $321.9 \pm 61.45$ \\
\hline $\mathrm{Mn}^{\mathrm{b}}$ & & $17.15 \pm 2.577$ & $11.48 \pm 2.007$ & $13.78 \pm 2.489$ & $15.06 \pm 2.565$ & $11.17 \pm 1.585$ & $12.17 \pm 2.432$ \\
\hline $\mathrm{Ni}^{\mathrm{a}}$ & & $\underline{69.80} \pm 15.50$ & $\underline{89.27} \pm 20.54$ & $\underline{98.71} \pm 16.91$ & $29.17 \pm 4.637$ & $36.73 \pm 6.020$ & $29.79 \pm 4.507$ \\
\hline $\mathrm{Ni}^{\mathrm{b}}$ & & $\underline{1.760} \pm 0.320$ & $\underline{1.470} \pm 0.326$ & $\underline{1.552} \pm 0.233$ & $1.266 \pm 0.201$ & $1.103 \pm 0.181$ & $1.171 \pm 0.204$ \\
\hline $\mathrm{P}^{\mathrm{a}}$ & & $655.0 \pm 77.40$ & $744.5 \pm 51.26$ & $699.1 \pm 58.69$ & $681.9 \pm 40.92$ & $798.6 \pm 72.48$ & $741.0 \pm 45.77$ \\
\hline $\mathrm{P}^{\mathrm{b}}$ & & $10.94 \pm 0.727$ & $13.01 \pm 0.781$ & $11.68 \pm 0.809$ & $12.01 \pm 1.201$ & $13.50 \pm 1.382$ & $12.99 \pm 0.716$ \\
\hline $\mathrm{Pb}^{\mathrm{a}}$ & & $16.18 \pm 3.346$ & $11.57 \pm 3.739$ & $11.84 \pm 2.467$ & $19.73 \pm 7.001$ & $11.88 \pm 4.011$ & $11.13 \pm 2.867$ \\
\hline $\mathrm{Pb}^{\mathrm{b}}$ & & $0.084 \pm 0.015$ & $0.043 \pm 0.027$ & $0.053 \pm 0.022$ & $0.068 \pm 0.024$ & $0.044 \pm 0.008$ & $0.058 \pm 0.010$ \\
\hline $\mathrm{Zn}^{\mathrm{a}}$ & & $67.31 \pm 13.26$ & $76.93 \pm 8.335$ & $73.24 \pm 8.231$ & $101.4 \pm 33.28$ & $113.2 \pm 48.84$ & $69.71 \pm 5.352$ \\
\hline $\mathrm{Zn}^{\mathrm{b}}$ & & $2.12 \pm 0.360$ & $1.51 \pm 0.322$ & $1.82 \pm 0.254$ & $2.533 \pm 0.831$ & $1.883 \pm 0.813$ & $2.074 \pm 0.098$ \\
\hline
\end{tabular}

Underlined values exceed the acceptable level in soil for the plants (see section Plant Selection and Polluted Area Description) $\mathrm{a}$ - aqua regia, $\mathrm{b}$ - ammonium nitrate.

pollution source (area A) and the soil sampled from an area approximately $2 \mathrm{~km}$ away from the pollution source (area B) were characterized by the physicochemical and chemical variables listed in Tables 1-3. All soil samples were sampled at a depth of 0-10 cm, from two different locations (with six replicates each) in area $A$ (coded with $A_{1}$ and $\mathrm{A}_{2}$ ), and from one location (with 50 replicates) in area $\mathrm{B}$ (coded with $\mathrm{B}_{1}$ ).

Furthermore, other soil samples were sampled from the rhizosphere of all three selected plant species $(n=54$ soil samples, of which 27 are from area A and 27 from area B), by shaking down the soil from the roots of the plants directly into labeled polyethylene bags. After sampling, the soil was placed in airtight plastic bags and transported to the laboratory in freezer, bags, where they were kept for 24 hours at $4^{\circ} \mathrm{C}$. Before determining any of the variables, the soil was well homogenized manually.

\section{Variables Measured on Soil Samples}

Using moist, unsieved soil, after removing any stones and/or plant debris, we determined the $\mathrm{pH}$, conductivity (EC), soil humidity, and mineral nitrogen and phosphate. The soil mixed with distilled water $(1: 2.5 \mathrm{~m} / \mathrm{v})$ was analyzed after stirring for 15 minutes and allowed to stand for one hour, in order to measure the $\mathrm{pH}$ and $\mathrm{EC}$ by means of a glass electrode and a conductivity probe from a multi-parameter kit WTW 340i (according to DIN ISO 112601997 $05)$. Soil humidity $(\mathrm{H})$ was determined by working with $10 \mathrm{~g}$ of wet soil that was brought to a constant weight at $105^{\circ} \mathrm{C}$. The determination of the pseudototal content of metals/metalloids and phosphorus was conducted according to the Hoffmann [17] method, after digesting the samples in aqua regia (suprapure acids from Merck, $\left.\mathrm{HCl}: \mathrm{HNO}_{3}=3: 1(\mathrm{v} / \mathrm{v})\right)$ by means of a pressure-assisted 
Table 5. p-values of the three plant species, of the polluted areas, and of the interaction factor for the soil variables.

\begin{tabular}{|c|c|c|c|c|c|c|c|c|c|c|c|}
\hline \multirow{3}{*}{$\begin{array}{c}\text { Adjusted } \\
\text { values of the } \\
\text { plant }\end{array}$} & \multirow{2}{*}{\multicolumn{3}{|c|}{ p-values }} & \multirow{3}{*}{$\begin{array}{l}\text { Adjusted } \\
\text { values of } \\
\text { the plant }\end{array}$} & \multicolumn{3}{|c|}{$\mathrm{AR}^{\mathrm{a}}$} & \multirow{3}{*}{$\begin{array}{l}\text { Adjusted } \\
\text { values of } \\
\text { the plant }\end{array}$} & \multirow{2}{*}{\multicolumn{3}{|c|}{$\frac{\mathrm{AN}^{\mathrm{b}}}{\mathrm{p} \text {-values }}$}} \\
\hline & & & & & \multicolumn{3}{|c|}{ p-values } & & & & \\
\hline & Species & Area & $\begin{array}{l}\text { Interaction } \\
\text { factor }\end{array}$ & & Species & Area & $\begin{array}{l}\text { Interaction } \\
\text { factor }\end{array}$ & & Species & Area & $\begin{array}{l}\text { Interaction } \\
\text { factor }\end{array}$ \\
\hline $\log (\mathrm{pH})$ & $<0.001$ & $<0.001$ & $<0.001$ & As & 0.297 & $<0.001$ & 0.031 & As & $<0.001$ & $<0.001$ & 0.167 \\
\hline $\mathrm{EC}$ & $<0.001$ & 0.001 & $<0.001$ & $\log (\mathrm{Cu})$ & 0.778 & 0.557 & 0.232 & $\log (\mathrm{Cu})$ & $<0.001$ & 0.362 & 0.013 \\
\hline $\log (\mathrm{U})$ & 0.091 & $<0.001$ & $<0.001$ & $\mathrm{Mn}$ & 0.011 & $<0.001$ & 0.072 & $\mathrm{Mn}$ & $<0.001$ & 0.038 & 0.488 \\
\hline $\log \left(\mathrm{N}-\mathrm{NH}_{4}^{+}\right)$ & 0.165 & $<0.001$ & 0.027 & $\mathrm{Ni}$ & 0.005 & $<0.001$ & 0.012 & $\log (\mathrm{Ni})$ & 0.030 & $<0.001$ & 0.917 \\
\hline $\log \left(\mathrm{N}-\mathrm{NO}_{3}^{-}\right)$ & 0.650 & $<0.001$ & 0.095 & $\log (\mathrm{Pb})$ & $<0.001$ & 0.550 & 0.433 & $\mathrm{~Pb}$ & $<0.001$ & 0.538 & 0.249 \\
\hline $\log \left(\mathrm{N}-\mathrm{NO}_{2}^{-}\right)$ & $<0.001$ & $<0.001$ & 0.066 & $1 / \mathrm{Zn}$ & 0.003 & $<0.001$ & 0.002 & $\log (Z n)$ & $<0.001$ & 0.022 & 0.982 \\
\hline $\log \left(\mathrm{P}-\mathrm{PO}_{4}^{3-}\right)$ & $<0.001$ & $<0.001$ & 0.116 & $1 / \mathrm{Cr}$ & 0.213 & $<0.001$ & 0.163 & $\mathrm{Cr}$ & $<0.001$ & $<0.001$ & 0.008 \\
\hline & & & & $\mathrm{P}$ & $<0.001$ & 0.015 & 0.804 & $\mathrm{P}$ & $<0.001$ & 0.001 & 0.399 \\
\hline
\end{tabular}

Bold - p-values indicate significant differences $(\mathrm{p}<0.05)$. ${ }^{\mathrm{a}} \mathrm{AR}$ - aqua regia, ${ }^{\mathrm{b}} \mathrm{AN}$ - ammonium nitrate

Table 6. p-values of the three plant species and polluted areas, as well as the $95 \%$ Confidence Intervals for the means.

\begin{tabular}{|c|c|c|c|c|c|}
\hline \multirow[b]{2}{*}{$\begin{array}{l}\text { Adjusted values } \\
\text { of the soil variables }\end{array}$} & \multicolumn{2}{|c|}{ p-values } & \multicolumn{3}{|c|}{ 95\% Confidence Intervals } \\
\hline & Species & Polluted areas & $\begin{array}{l}1 \\
2\end{array}$ & $\begin{array}{l}1 \\
3\end{array}$ & $\begin{array}{l}2 \\
3\end{array}$ \\
\hline $\log \left(\mathrm{N}-\mathrm{NO}_{3}^{-}\right)$ & 0.666 & $<0.001$ & $(-1.116,1.559)$ & $(-1.469,1.178)$ & $(-1.583,0.850)$ \\
\hline $\log \left(\mathrm{N}-\mathrm{NO}_{2}^{-}\right)$ & $<0.001$ & $<0.001$ & $(0.2451,1.3204)^{*}$ & $(0.1134,1.1887)^{*}$ & $(-0.6197,0.3562)$ \\
\hline $\log \left(\mathrm{P}^{-} \mathrm{PO}_{4}^{3-}\right)$ & $<0.001$ & $<0.001$ & $(0.1601,0.7624)^{*}$ & $(-0.1756,0.4266)$ & $(-0.6091,-0.0625)^{*}$ \\
\hline \multicolumn{6}{|l|}{ Aqua regia } \\
\hline $\log (\mathrm{Cu})$ & 0.782 & 0.401 & $(-0.2446,0.1340)$ & $(-0.2199,0.1588)$ & $(-0.1471,0.1965)$ \\
\hline $\mathrm{Mn}$ & 0.014 & $<0.001$ & $(-308.3,83.8)$ & $(-269.4,122.8)$ & $(-138.9,216.9)$ \\
\hline $\log (\mathrm{Pb})$ & $<0.001$ & 0.681 & $(-0.6609,-0.2134)^{*}$ & $(-0.6588,-0.2113)^{*}$ & $(-0.2009,0.2052)$ \\
\hline $1 / \mathrm{Cr}$ & 0.224 & $<0.001$ & $(-0.0122,0.0172)$ & $(-0.0145,0.0149)$ & $(-0.0156,0.0110)$ \\
\hline $\mathrm{P}$ & $<0.001$ & 0.010 & $(51.45,154.75)^{*}$ & $(-0.05,103.25)$ & $(-98.37,-4.62)^{*}$ \\
\hline \multicolumn{6}{|l|}{ Ammonium nitrate } \\
\hline As & $<0.001$ & $<0.001$ & $(-0.0059,-0.0014)^{*}$ & $(-0.0057,-0.0012)^{*}$ & $(-0.0017,0.0022)$ \\
\hline $\mathrm{Mn}$ & $<0.001$ & 0.047 & $(-6.740,-2.831)^{*}$ & $(-5.086,-1.178)^{*}$ & $(-0.120,3.427)$ \\
\hline $\log (\mathrm{Ni})$ & 0.026 & $<0.001$ & $(-0.3547,0.0240)$ & $(-0.2902,0.0885)$ & $(-0.1073,0.2363)$ \\
\hline $\mathrm{Pb}$ & $<0.001$ & 0.732 & $(-0.0483,-0.0167)^{*}$ & $(-0.0360,-0.0044)^{*}$ & $(-0.0020,0.0266)$ \\
\hline $\log (\mathrm{Zn})$ & $<0.001$ & 0.018 & $(-0.5411,-0.1403)^{*}$ & $(-0.3565,0.0444)$ & $(0.0027,0.3665)^{*}$ \\
\hline $\mathrm{P}$ & $<0.001$ & 0.001 & $(0.878,2.681)^{*}$ & $(-0.041,1.762)$ & $(-1.738,-0.101)^{*}$ \\
\hline
\end{tabular}

Bold - p-values indicate significant differences $(\mathrm{p}<0.05), *^{*}$ indicates significant differences between plant species

digestion system (Microwave 3000 Anton Paar), using a three-step program with progressive increase of IR up to $210^{\circ} \mathrm{C}$ and of pressure up to $40 \mathrm{bar}(0.3 \mathrm{bar} / \mathrm{s})$ for $65 \mathrm{~min}$., without filtering the samples before measuring. Every digestion batch had one blank and two analytical replicates. Single chemical extraction in $1 \mathrm{M} \mathrm{NH}_{4} \mathrm{NO}_{3}$ p.a. Merck solu- tion was used for the estimation of potentially available element content by working with $20 \mathrm{~g}$ of air-dried and sieved $(<2 \mathrm{~mm})$ soil and $50 \mathrm{ml}$ ammonium nitrate, and using an overhead shaker (GFL 3040), at $10 \mathrm{rpm}$ [18]. For the second step of this method, all samples were centrifuged at 6000 rpm for 20 minutes and the supernatant was filtered using 
$0.45 \mu \mathrm{m}$ cellulose acetate filters and preserved with suprapure $65 \% \mathrm{HNO}_{3}$. The analysis of the ions of solution elements was done using mass spectrometry with inductively coupled plasma ICP-MS, Perkin-Elmer ELAN DRC-e with axial field technology for trace and rare earth element analyses (the DRC-e is a dynamic reaction cell placed before the traditional quadrupole chamber of the ICP-MS device for the purpose of eliminating isobaric interference; this chamber is filled with reaction methane gas, which reacts with the introduced sample, eliminating some of the interference). Standard solutions were prepared by diluting a $10-\mu \mathrm{g} / \mathrm{ml}$ multielement solution (multielement ICP calibration standard 3, matrix 5\% $\mathrm{HNO}_{3}$, Perkin Elmer Pure Plus).

Other variables measured during the two sampling campaigns were mineral nitrogen $\left(\mathrm{N}-\mathrm{NH}_{4}^{+}, \mathrm{N}^{-\mathrm{NO}_{3}^{-}}\right.$, and $\left.\mathrm{N}-\mathrm{NO}_{2}^{-}\right)$ and available phosphorus $\left(\mathrm{P}-\mathrm{PO}_{4}^{3-}\right)$. The procedure of extracting mineral nitrogen was performed by using $20 \mathrm{~g}$ of fresh soil with potassium chloride $(100 \mathrm{ml} 0.2 \mathrm{M} \mathrm{KCl})$ for one hour, whereas for the available phosphorus $\left(\mathrm{P}^{-} \mathrm{PO}_{4}^{3-}\right)$, $5 \mathrm{~g}$ of soil were used with sodium hydrogen carbonate (100 $\mathrm{ml} 0.5 \mathrm{M} \mathrm{NaHCO}_{3}$ ) for half an hour. Afterward, the extract was filtered using a glass filter (Whatmann GF/C) and analyzed by colorimetric methods (according to the methods described by Neagoe et al. [19].

\section{Variables Measured on Plant Samples}

Seven dandelion replicates (Taraxacum officinale) and 10 replicates of clover (Lotus corniculatus) and plantain (Plantago major) were sampled from each site and transported to the laboratory in a cooler bag. These will be further referred to as species 1, species 2, and species 3, respectively. Then, they were separated in roots and aboveground part of plants (the stem together with the leaves, and the flowers separately) in order to assess the variables of oxidative stress and the content of metals/metalloids and phosphorus. After separating the underground part from the aboveground one, the roots were quickly washed with lots of tap water, rinsed several times with distilled water, and finally with ultrapure water. The entire plant material was weighed, dried through lyophillization, ground by means of a cooler stainless steel mill (IKA, 156 A11basic) to a very fine powder, and frozen at $-45^{\circ} \mathrm{C}$ until further processing. In all plant parts, the content of metals/metalloids and phosphorus was determined after microwave digestion with suprapure nitric acid (65\%) using a three-step program with progressive increase of IR up to $140^{\circ} \mathrm{C}$ and pressure up to $40 \mathrm{bar}(0.3 \mathrm{bar} / \mathrm{s})$, for $45 \mathrm{~min}$. Every digestion batch had one blank and two analytical replicates. The quality assurance and quality control criteria were satisfied by checking the standard reference material CRM 281 of ryegrass. The differences were of no more than 5\%. The element analysis was performed using ICP-MS (the same instrument as described in the soil section). For protein and enzyme assays, dry plant material (50 or $100 \mathrm{mg}$ ) was homogenized in $4 \mathrm{ml}$ cold $100 \mathrm{mM}$ potassium phosphate buffer $(\mathrm{pH}$ 7.2) containing $2 \%$ polyvinylpyrolidone $2 \mathrm{mM}$ EDTA and 2 $\mathrm{mM}$ dithioerithrol, and centrifuged at $6,000 \mathrm{rpm}$ for 20 minutes at $4^{\circ} \mathrm{C}$. The supernatant was dialyzed overnight at $4^{\circ} \mathrm{C}$ in $5 \mathrm{mM}$ potassium phosphate buffer ( $\mathrm{pH}$ 7.2). Protein concentrations were determined spectrophotometrically with alkaline copper reagent and Folin-Ciocâlteu reagent against a BSA standard curve (according to Lowry et al. [20]). Superoxide dismutase was measured through the inhibition of the reduction rate of Cytochrome $\mathrm{c}$ by the superoxide radical, observed at $550 \mathrm{~nm}$ (according to McCord and Fridovich [21]). Peroxidase activity was determined spectrophotometrically by measuring the transformation of guajacol to tetraguajacol in the presence of $\mathrm{H}_{2} \mathrm{O}_{2}$. The reaction mixture contained $33 \mathrm{mM}$ guajacol and $0.3 \mathrm{mM} \mathrm{H}_{2} \mathrm{O}_{2}$ in $50 \mathrm{mM}$ citrate/phosphate buffer ( $\mathrm{pH} \mathrm{5)}$ (according to Lagrimini [22]; more details can be found in Neagoe et al. [19]). The estimation of lipid peroxides involves the determination of malondialdehyde, resulting from the decomposition of peroxides of polyunsaturated fatty acids, by using thiobarbituric acid and the colorimetric method at room temperature. Tests were performed in the following way: $20 \mathrm{mg}$ of dry biomass were homogenized with $4 \mathrm{ml}$ TBA solution containing 10\% trichloroacetic acid and $0.25 \%$ thiobarbituric acid in ultrapure water, heated for $30 \mathrm{~min}$ at $95^{\circ} \mathrm{C}$, cooled for $15 \mathrm{~min}$ at room temperature, and centrifuged and measured spectrophotometrically at 440, 532, and $600 \mathrm{~nm}$ using an equation described by Hodges et al. [23]. In addition, the photosynthetic pigments chlorophyll $a$ and $b$ and the carotenoids were assayed using $50 \mathrm{mg}$ of dry aboveground plant matter. Plant samples were homogenized with a v:v solution of $80 \%$ acetone, $15 \%$ water, and $5 \%$ solution of $\mathrm{NH}_{3}(25 \%$ concentration). Samples were then centrifuged to remove solids, and to obtain a clear supernatant without being filtered before being spectrophotometrically measured at 480 , $645,647,663$, and $664 \mathrm{~nm}$, in order to determine the photosynthetic pigments chlorophyll $a$, chlorophyll $b$, and carotenoids, according to the Schopfer method [24].

\section{Statistical Analysis}

Data were analyzed using the Minitab statistical software package (version 15.0). The test used was 2-way ANOVA, which performs an analysis for testing the equality of population means when classification is by two variables. Since one of the two-way ANOVA assumptions is normality of the data, a transformation (either log (response), or 1/response) was applied to the response variable when required. Normality of the data is required as this statistical test cannot be performed if there is concern that there is too much skewness in the data or potential for outliers. The assumption of normality was checked by plotting the data on a Q-Q Plot and checking whether the points followed the equality line. If they did, then the assumption of normality was satisfied. For all the cases when the data were adjusted, the p-values and the 95\% Confidence Intervals were calculated using the adjusted values. If the $p$-value of the interaction factor is greater than 0.05 ( $>0.05$ ), it means that there is no interaction factor, in which case this is eliminated. The Confidence Intervals allow us to assess the practical significance of differences among means, in addition to statistical significance. If the 
Table 7. Element concentration in plants.

\begin{tabular}{|c|c|c|c|c|c|c|c|c|c|c|}
\hline Area & Roots & Units & As & $\mathrm{Cr}$ & $\mathrm{Cu}$ & $\mathrm{Mn}$ & $\mathrm{Ni}$ & $\mathrm{P}$ & $\mathrm{Pb}$ & $\mathrm{Zn}$ \\
\hline \multirow{3}{*}{ A } & Dandelion & \multirow{6}{*}{$\begin{array}{l}3 \\
0 \\
0 \\
b_{0} \\
\dot{6} 0 \\
=\end{array}$} & $0.593 \pm 0.063$ & $7.643 \pm 2.299$ & $13.31 \pm 1.605$ & $131.1 \pm 64.86$ & $13.86 \pm 3.118$ & $937.5 \pm 166.8$ & $4.43 \pm 1.754$ & $59.74 \pm 27.48$ \\
\hline & Clover & & $0.517 \pm 0.11$ & $7.204 \pm 2.705$ & $11.18 \pm 3.421$ & $31.68 \pm 24.6$ & $9.113 \pm 5.066$ & $733.0 \pm 207.8$ & $3.896 \pm 2.828$ & $38.41 \pm 18.44$ \\
\hline & Plantain & & $0.689 \pm 0.218$ & $7.684 \pm 2.69$ & $12.7 \pm 1.012$ & $37.5 \pm 11.94$ & $5.221 \pm 1.05$ & $1290 \pm 328.7$ & $4.498 \pm 1.571$ & $80.0 \pm 23.62$ \\
\hline \multirow{4}{*}{ B } & Dandelion & & $0.423 \pm 0.053$ & $1.34 \pm 0.577$ & $13.33 \pm 2.234$ & $40.09 \pm 10.17$ & $1.973 \pm 1.206$ & $1684 \pm 621.5$ & $8.441 \pm 5.275$ & $72.63 \pm 11.86$ \\
\hline & Clover & & $0.422 \pm 0.059$ & $1.039 \pm 0.589$ & $15.25 \pm 3.381$ & $44.76 \pm 11.78$ & $2.028 \pm 1.149$ & $623.1 \pm 565.7$ & $4.482+4.653$ & $64.26 \pm 26.38$ \\
\hline & Plantain & & $0.378 \pm 0.099$ & $1.507 \pm 0.741$ & $16.99 \pm 3.543$ & $47.89 \pm 13.09$ & $3.364 \pm 1.661$ & $1501.6 \pm 301.6$ & $6.803 \pm 2.375$ & $92.29 \pm 19.81$ \\
\hline & Shoots* & & & & & & & & & \\
\hline \multirow{3}{*}{ A } & Dandelion & \multirow{6}{*}{$\begin{array}{l}\dot{B} \\
\overrightarrow{0} \\
\dot{b} 0 \\
\dot{0} 0 \\
\vec{E}\end{array}$} & $0.446 \pm 0.109$ & $5.634 \pm 2.466$ & $4.122+0.839$ & $80.45 \pm 16.4$ & $7.636 \pm 4.524$ & $923.2 \pm 108.9$ & $2.916 \pm 0.947$ & $14.79 \pm 4.705$ \\
\hline & Clover & & $0.449 \pm 0.078$ & $3.864 \pm 1.454$ & $7.582 \pm 1.276$ & $34.2 \pm 7.503$ & $4.196 \pm 1.523$ & $1315 \pm 246.9$ & $3.305 \pm 1.265$ & $20.46 \pm 5.13$ \\
\hline & Plantain & & $0.445 \pm 0.058$ & $6.929 \pm 5.328$ & $5.417 \pm 1.126$ & $37.97 \pm 27.85$ & $4.57 \pm 4.025$ & $1363 \pm 525.5$ & $4.271 \pm 2.19$ & $24.58 \pm 11.26$ \\
\hline \multirow{4}{*}{ B } & Dandelion & & $0.399 \pm 0.042$ & $0.798 \pm 0.249$ & $6.597 \pm 2.585$ & $38 \pm 10.06$ & $0.682 \pm 0.712$ & $2018 \pm 865.8$ & $6.796 \pm 1.059$ & $27.52 \pm 13.17$ \\
\hline & Clover & & $0.359 \pm 0.02$ & $0.863 \pm 0.521$ & $7.205 \pm 0.085$ & $41.47 \pm 9.562$ & $0.822+0.465$ & $1331 \pm 501.8$ & $3.996 \pm 1.196$ & $28.74 \pm 27.58$ \\
\hline & Plantain & & $0.329 \pm 0.139$ & $0.835 \pm 0.363$ & $6.269 \pm 0.623$ & $45.09 \pm 12.4$ & $1.057 \pm 0.358$ & $1952 \pm 411$ & $5.901 \pm 1.116$ & $32.2 \pm 24.19$ \\
\hline & Flowers** & & & & & & & & & \\
\hline \multirow{3}{*}{ A } & Dandelion & \multirow{6}{*}{ 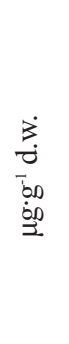 } & $0.419 \pm 0.037$ & $4.20 \pm 0.965$ & $9.479 \pm 1.326$ & $108.0 \pm 17.97$ & $11.63 \pm 1.379$ & $2610 \pm 210$ & $3.971 \pm 1.603$ & $33.56 \pm 4.44$ \\
\hline & Clover & & 0.449־0.116 & $6.856 \pm 4.597$ & $9.368 \pm 1276$ & $25.99 \pm 5.136$ & $9.51 \pm 2.078$ & $2686 \pm 212.2$ & $3.706 \pm 1.613$ & $34.04 \pm 5.615$ \\
\hline & Plantain & & $0.362+0.057$ & $2.446 \pm 1.443$ & $6.452 \pm 1.687$ & $24.38 \pm 12.92$ & $2.309 \pm 0.957$ & $1845 \pm 712.3$ & $2.645 \pm 1.494$ & $28.56 \pm 13.35$ \\
\hline \multirow{3}{*}{ B } & Dandelion & & $0.247 \pm 0.019$ & $0.63 \pm 0.218$ & $5.094 \pm 0.997$ & $51.88 \pm 15.56$ & $0.354 \pm 0.357$ & $3199 \pm 996.2$ & $6.034 \pm 4.108$ & $44.46 \pm 11.95$ \\
\hline & Clover & & $0.242 \pm 0.03$ & $0.572+0.289$ & $5.993 \pm 0.963$ & $85.33 \pm 61.19$ & $0.671 \pm 0.146$ & $3077 \pm 501.7$ & $7.039 \pm 4.054$ & $48.05 \pm 22.12$ \\
\hline & Plantain & & $0.239 \pm 0.026$ & $0.557 \pm 0.221$ & $5.12 \pm 1.451$ & $66.55 \pm 48.03$ & $0.596 \pm 0.486$ & $2826 \pm 540.6$ & $5.996 \pm 2.521$ & $31.43 \pm 11.91$ \\
\hline
\end{tabular}

*Aboveground part of plants, **Inflorescence

Confidence Interval does not contain the zero value, it means that there is a difference between means. The results of the ANOVA test and the Tukey comparison can conflict. For example, it is possible for the ANOVA to reject the hypothesis of no differences among the level means, and yet for all the Tukey-pairwise Confidence Intervals to contain zero value [25]. A correlation analysis (Pearson's Correlation) was performed between the concentrations in soil and their concentrations in different plant parts.

\section{Results and Discussion}

In areas $\mathrm{A}_{1}$ and $\mathrm{B}_{1}$, the soils showed low acidic content (Table 1), whereas in area $\mathrm{A}_{2}$ there was neutral $\mathrm{pH}$, according to the INRA classification [26]. Concerning the nitrogen (ammonia, nitrate, and nitrite) content, in $\mathrm{A}_{1}$ and $\mathrm{A}_{2}$, there was a very low level in all the measured samples due to a lack of mineral $\mathrm{N}$, whereas in $\mathrm{B} 1$ the concentration was higher, which could be considered sufficient value for the development of many plants, according to Griffin [27]. The available phosphorus presented higher concentrations in all soil samples. These concentrations are considered optimum values for the development of many plant species according to Howard [28], who reported that agronomic thresholds are less than $60 \mathrm{mg} \cdot \mathrm{kg}^{-1}$. The EC registered low values, corresponding to the unsalinated soil class $(0-2 \mathrm{mS} / \mathrm{cm})$ according to Arshad and Martin [29]. Regarding the pseudo-total content of $\mathrm{As}, \mathrm{Cr}, \mathrm{Mn}$, and $\mathrm{Ni}$, due to the anthropogenic inputs, we recorded concentrations above the acceptable values for plant growth in soil (Table 2), as found by Effroymson et al. [30] and Kabata-Pendias and Pendias [31], which were of 2-10 $\mu \mathrm{g} \cdot \mathrm{g}^{-1}$ for As, 50-100 $\mu \mathrm{g} \cdot \mathrm{g}^{-1}$ for $\mathrm{Cr}$, 30$35 \mu \mathrm{g} \cdot \mathrm{g}^{-1}$ for $\mathrm{Ni}$, and $100-500 \mu \mathrm{g} \cdot \mathrm{g}^{-1}$ for $\mathrm{Mn}$, whereas $\mathrm{Cu}$ was below the acceptable limit of $30-100 \mu \mathrm{g} \cdot \mathrm{g}^{-1}$. On the other hand, $\mathrm{Pb}$ and $\mathrm{Zn}$ were found in concentrations acceptable for plant growth in soil $\left(2-60 \mu \mathrm{g} \cdot \mathrm{g}^{-1}\right.$ for $\mathrm{Pb}$ and $17-125$ $\mu \mathrm{g} \cdot \mathrm{g}^{-1}$ for $\mathrm{Zn}$ ). If we compare the contents of the pseudototal and available forms of these elements (Table 3 ), we can observe that the pseudo-total content of investigated elements is linearly positively correlated with extractable forms. This positive correlation was also found by Senila [32], who used $1 \mathrm{M} \mathrm{HCl}$ instead of $1 \mathrm{M} \mathrm{NH}_{4} \mathrm{NO}_{3}$ (as in our measurements). This author's explanation is that both aqua regia and diluted $\mathrm{HCl}$ can attack the potentially mobile elements from soil, but not the elements bound in the silicate matrix, which was confirmed by our results using diluted $\mathrm{NH}_{4} \mathrm{NO}_{3}$. 


\section{Physicochemical Characteristics of Soils Sampled from Rhizospheres}

Physicochemical variables show that the soils from the rizosphere of the three plant species (A area) are acidic $(\mathrm{pH}$ between 5 and 6.5 according to INRA, [26]) while in the case of area B an acidic $\mathrm{pH}$ was found only in the rhizosphere of dandelion, and in the clover and plantain rhizospheres the $\mathrm{pH}$ was within the upper limit of the class of neutral soils (6.5-7.7) (Table 4). These findings are according to our own results presented above (for areas $A_{1}, A_{2}$ and $B_{1}$ ), and also to the study performed by Becherescu et al. [33] on a surface of approximately 100 ha near the same polluted area. EC was lower in the A dandelion rhizosphere as compared to other A and B rhizospheres. However, both $\mathrm{A}$ and $B$ areas belong to the unsalinated soils category $(0-2 \mathrm{mS} / \mathrm{cm}$ according to Arshad and Martin [29]). If we look at humidity values, we can see that the soil of plants collected from the $\mathrm{B}$ rizospheres was drier than that of A. In area A the concentrations of mineral $\mathrm{N}$ were statistically significantly lower in the soil from the rhizosphere of all three plant species. Moreover, in all three rhizospheres in area A, mineral $\mathrm{N}$ had values below $20 \mu \mathrm{g} \cdot \mathrm{g}^{-1} \mathrm{~d}$.w., which means that it belongs to the class of soils with a low level of supply for wild plants, whereas for area B the concentrations fluctuated between $61-100 \mu \mathrm{g} \cdot \mathrm{g}^{-1} \mathrm{~d}$.w., which is characteristic for the soils with a high level of supply according to Griffin [27].

The concentration of bioavailable $\mathrm{P}$ using the $\mathrm{NaHCO}_{3}$ extractant showed, as in the case of $\mathrm{N}$, higher values in area $\mathrm{B}$, ranging between the $18.1-36 \mu \mathrm{g} \cdot \mathrm{g}^{-1} \mathrm{~d}$.w. These values are specific to the soils with an average level of supply, and were compared to the values registered in area $\mathrm{A}$, where the concentration of $\mathrm{P}$ ranged between 8.1-18 $\mu \mathrm{g} / \mathrm{g}$ d.w., values specific to the soils with low supply, according to Howard [28]. Moreover, if we compare the concentrations of available $\mathrm{P}$ obtained by extraction with $\mathrm{NaHCO}_{3}$ with those obtained using $\mathrm{NH}_{4} \mathrm{NO}_{3}$, we observe that the latter had much lower values. Comparing the pseudo-total concentrations of elements such as $\mathrm{As}, \mathrm{Cr}, \mathrm{Mn}, \mathrm{Ni}, \mathrm{Cu}, \mathrm{Pb}$, and $\mathrm{Zn}$ determined in the soil from the rhizosphere of the three plant species, it was observed that in area A elements such as As, $\mathrm{Cr}, \mathrm{Mn}$, and Ni were found in concentrations exceeding the acceptable level in soil for plants which can be used by the human population (according to Effroymson et al. [30] and Kabata-Pendias and Pendias [31]). In the case of $\mathrm{Cu}$, a deficiency could be observed, while for $\mathrm{Pb}$ and $\mathrm{Zn}$, acceptable concentrations were registered that do not affect the growth of plants from spontaneous flora.

The presence of metals in soils from this polluted area was also mentioned in the research project conducted by the City of Slatina [16]. Many authors have demonstrated that there is a necessity to identify the chemical forms in which the elements exist in soils. These forms can strongly influence their speciation and are used for estimating their bioavailability, their physicochemical reactivity and their mobility into the food chain [34]. In general, mobile forms are more toxic to plant growth than strongly complex forms
[35]. In our study, the bioavailable form of these elements determined in the rhizosphere soils shows a pattern of variation similar to that found in the case of the soils sampled from areas $A_{1}, A_{2}$, and $B_{1}$, as described above.

Metals must be in soluble form to be absorbed by the plant root system. Hydroxides and carbonates of metals are in general quite insoluble, and the possibility of forming insoluble hydroxides and carbonates increases when the $\mathrm{pH}$ is higher. To minimize toxic metal availability, soil $\mathrm{pH}$ should be maintained around 6.5 by amendment. As expected, in our study the mobilization of elements, with the exception of $\mathrm{P}$, increased as a result of alleviating soil $\mathrm{pH}$ acidity as can be seen in Table 4 . Metals bound to the bioavailable fraction were also found by the Zheng et al. [36] to be very sensitive to $\mathrm{pH}$ changes. Also, Smith [27] found that very low transfers of metals to plant tissues occur at high $\mathrm{pH}$.

The $\mathrm{pH}$ value below which the mobility and biological availability and toxic metals increase was approximated (in $\mu \mathrm{g} / \mathrm{g}$ ) by Martinez and Motto [37] for some elements such as for $\mathrm{Pb}$ (5.2), $\mathrm{Zn}$ (6.2), and $\mathrm{Cu}$ (5.5). Another factor that can strongly influence the ability of some elements to be phytotoxic in soil is organic matter [38, 39]. Because this depends to an extent on soil type [40], respectively, on the presence of soluble organo-metal complexes in soil, we can clearly state that organic matter played an important role in our studied soils, which showed a 5-8 cm layer of cemented organic matter [16]. On the other hand, the formation of humic substances could transform $\mathrm{Zn}$ from a potentially existing sulfide fraction (which could come from such waste gases as the sulphur dioxide $\mathrm{SO}_{2}$ [12]). To an organic fraction, which is a form not easily accessible to plants. The oxido-reduction states of the mineral components as well as the redox potential of the system also influence the mobility of the elements. For instance, $\mathrm{Cr}$ is commonly present in soils as $\mathrm{Cr}$ (III) and $\mathrm{Cr}(\mathrm{VI})$. These forms present distinctive chemical properties and toxicities [41]. Cr (VI) is 10 up to 100 times more toxic than $\mathrm{Cr}(\mathrm{III})$, thus being a strong oxidizing agent, while non-hazardous $\mathrm{Cr}$ (III) is insoluble in water and plays a beneficial role as a micronutrient [6]. For the $\mathrm{Pb}$ in soil the most common form is sulfate $\left(\mathrm{PbSO}_{4}\right)$, the organic phase often being related to the soil, in combination with $\mathrm{Mn}$ and Fe oxides or carbonates. $\mathrm{Pb}^{2+}$ has a stronger affinity to the adsorption sites on the clay materials. $\mathrm{Zn}$ in soil forms complexes with chlorides, phosphates, nitrates, and sulfates. In the case of $\mathrm{Zn}$, based on the redox potential, $\mathrm{Zn}^{2+}$ can be expected to stay in ionic form in solution. It seems that the $\mathrm{ZnSO}_{4}$ and $\mathrm{ZnHPO}_{4}$ forms are the most important as they contribute significantly to the concentration of $\mathrm{Zn}$ in soils, thus increasing $\mathrm{Zn}$ solubility and mobility. $\mathrm{Zn}$ forms soluble complexes with the fulvic acids, leading to an increase in its mobility $[6,41]$.

From a statistical point of view, p-values for three plant species for polluted areas A and B, and for the interaction factor for the related rhizosphere soils were calculated. Also, a comparison between every two species of plants (1-2, 1-3, 2-3) was made using the Tukey - all pairwise 
Table 8. p-values of the species, polluted areas, and interaction factor for elements from the plant part.

\begin{tabular}{|c|c|c|c|c|c|c|c|c|c|c|c|}
\hline \multirow{2}{*}{$\begin{array}{l}\text { Adjusted } \\
\text { values of } \\
\text { the plant } \\
\text { variable }\end{array}$} & \multicolumn{3}{|c|}{ Roots p-values } & \multirow{2}{*}{$\begin{array}{l}\text { Adjusted } \\
\text { values of } \\
\text { the plant } \\
\text { variable }\end{array}$} & \multicolumn{3}{|c|}{ Aboveground p-values } & \multirow{2}{*}{$\begin{array}{l}\text { Adjusted } \\
\text { values of } \\
\text { the plant } \\
\text { variable }\end{array}$} & \multicolumn{3}{|c|}{ Inflorescence $p$-values } \\
\hline & Species & Area & $\begin{array}{l}\text { Interaction } \\
\text { factor }\end{array}$ & & Species & Area & $\begin{array}{c}\text { Interaction } \\
\text { factor }\end{array}$ & & Species & Area & $\begin{array}{c}\text { Interaction } \\
\text { factor }\end{array}$ \\
\hline $\log (\mathrm{As})$ & 0.487 & $<0.001$ & 0.012 & As & 0.499 & 0.001 & 0.519 & $\log (\mathrm{As})$ & 0.077 & $<0.001$ & 0.146 \\
\hline $\log (\mathrm{Cr})$ & 0.295 & $<0.001$ & 0.603 & $\log (\mathrm{Cr})$ & 0.565 & $<0.001$ & 0.202 & $\log (\mathrm{Cr})$ & 0.007 & $<0.001$ & 0.013 \\
\hline $\mathrm{Cu}$ & 0.108 & 0.001 & 0.071 & $\mathrm{Cu}$ & $<0.001$ & 0.007 & 0.009 & $\log (\mathrm{Cu})$ & $<0.001$ & $<0.001$ & 0.023 \\
\hline $\log (\mathrm{Mn})$ & $<0.001$ & 0.269 & $<0.001$ & $\log (\mathrm{Mn})$ & 0.002 & 0.316 & $<0.001$ & $\log (\mathrm{Mn})$ & $<0.001$ & 0.002 & $<0.001$ \\
\hline $\log (\mathrm{Ni})$ & 0.563 & $<\mathbf{0 . 0 0 1}$ & $<0.001$ & $\log (\mathrm{Ni})$ & 0.977 & $<0.001$ & 0.008 & $\log (\mathrm{Ni})$ & $<0.001$ & $<0.001$ & $<0.001$ \\
\hline $\mathrm{Pb}$ & 0.022 & 0.492 & 0.202 & $\log (\mathrm{Pb})$ & 0.022 & $<0.001$ & 0.028 & $\log (\mathrm{Pb})$ & 0.339 & $<0.001$ & 0.269 \\
\hline $\mathrm{Zn}$ & $<0.001$ & 0.001 & 0.182 & $\log (\mathrm{Zn})$ & 0.188 & 0.010 & 0.511 & $\log (Z n)$ & 0.004 & 0.016 & 0.680 \\
\hline $\mathrm{P}$ & $<0.001$ & 0.013 & 0.014 & $\log (\mathrm{P})$ & 0.158 & $<0.001$ & 0.013 & $\log (\mathrm{P})$ & 0.006 & $<0.001$ & 0.280 \\
\hline
\end{tabular}

Bold - p-values indicate significant differences $(\mathrm{p}<0.05)$

approach, and the results are presented in Tables 5 and 6 . Given the issues outlined in the statistical analysis section, we could observe that there are statistically significant differences between species in the case of the following soil variables: $\mathrm{pH}, \mathrm{EC}, \mathrm{N}-\mathrm{NO}_{2}^{-}, \mathrm{P}^{-} \mathrm{PO}_{4}^{3-}$, pseudo-total concentrations of $\mathrm{Mn}, \mathrm{Ni}, \mathrm{Pb}, \mathrm{Zn}$, and $\mathrm{P}$, and all easily extractable elements: $\mathrm{As}, \mathrm{Cu}, \mathrm{Cr}, \mathrm{Mn}, \mathrm{Ni}, \mathrm{P}, \mathrm{Pb}$, and $\mathrm{Zn}$. Moreover, for most of the variables (except for $\mathrm{Cu}$ and $\mathrm{Pb}$ in the two forms: pseudo-total and easily extractable) there were statistically significant differences between the polluted areas. Every two species were then compared by calculating 95\% Confidence Intervals for the means of the soil variables. We could see that in the case of $\mathrm{N}^{-} \mathrm{NO}_{2}{ }^{-}, \mathrm{Pb}$ in both forms, easily extractable As and easily extractable $\mathrm{Mn}$, there was a difference between species 1 and 2, and 1 and 3. In addition, the content of $\mathrm{P}_{-} \mathrm{PO}_{4}^{3-}$, easily extractable $\mathrm{Zn}$ and $\mathrm{P}$ in the two forms was different between species 1 and 2 , and 2 and 3. For all the others, there was no sufficient evidence of a difference between species, since the $95 \%$ Confidence Interval did not contain the zero value. We could also observe that while the 2-way ANOVA gave a difference between species for $\mathrm{Mn}(\mathrm{p}=0.014)$, the Tukey comparison showed that there was no evidence of a difference, which once again proved that these two can sometimes conflict. What is more, for example, the rizosphere soil of clover species has a content of $\mathrm{N}^{-\mathrm{NO}_{2}^{-}}$higher than that of dandelion species by a value between $\exp (0.2451)$ and $\exp (1.3204)$, hence between 1.278 and $3.745 \mu \mathrm{g} \cdot \mathrm{g}^{-1}$. The content of $\mathrm{N}^{-} \mathrm{NO}_{2}^{-}$in the rizosphere soil of plantain species is higher than that of the dandelion species by a value between $\exp (0.1134)$ and $\exp (1.1887)$, hence between 1.120 and $3.283 \mu \mathrm{g} \cdot \mathrm{g}^{-1}$. The difference in the $\mathrm{N}^{-\mathrm{NO}_{2}^{-}}$content between the rhizosphere soil of the plantain species and clover species lies somewhere between $\exp (-0.6197)$ and $\exp (0.3562)$, that is between 0.5138 and $1.428 \mu \mathrm{g} \cdot \mathrm{g}^{-1}$. This variation of nitrite content in rhizospheres might be due to differential oxygen release by the roots of the three plant species. By releasing oxygen into the rhizosphere, a protective oxidative film is formed around the surface of the roots.
Systems without plants are totally different from those with plants, which have a significant influence on the redox potential that fluctuates strongly in the rhizosphere [42]. The nitrite evolution could also suggest an accumulation of $\mathrm{NO}$ and $\mathrm{N}_{2} \mathrm{O}$ in soil. Moreover, the nitrite could be reduced using sulphides (probably as electron donors), which might be generated into soils as result of the presence of sulphate in the polluted areas. We can conclude that there are statistically significant differences, both between the rhizosphere of plant species and the two polluted areas A and B.

\section{Element Concentration in Plants}

In the present study, we tried to get a response regarding the pollution level after analyzing the element content in different parts of selected plants grown in both areas A and B. Although in terms of the elements analyzed in different plant parts, a level of pollution was registered, they developed just as vigorously in both investigated areas. But it is well documented that terrestrial plants have developed complex strategies for the efficient acquisition of essential metal micronutrients and for resistance to highly accumulated concentrations [43]. Many other authors also investigated the heavy metal concentration in different plant parts. Thus they used a non-destructive method without harvesting the whole plant individual, in order to conclude that these plant species can be bioindicators. They described the evolution of a pollutant over a longer period of time [44, 45]. However, many previous studies have revealed the phytotoxic effects of metals translocated from soil to roots and their aboveground parts. The phytotoxic effects are manifested on plant growth and also on the physiological and molecular plant processes [44, 46]. They adopt adaptive strategies to survive at high concentrations of metals and complete their life cycle [47]. The translocation of elements from soil into root and then to aboveground parts of plants is dependent on the mobility of elements in the rhizosphere, but especially on the bioavailability of each plant species [48]. 
Table 9. p-values of the species, polluted areas as well as the $95 \%$ Confidence Intervals for the means for the plant parts.

\begin{tabular}{|c|c|c|c|c|c|}
\hline $\begin{array}{l}\text { Adjusted values of } \\
\text { the soil variables }\end{array}$ & \multicolumn{2}{|c|}{ p-values } & \multicolumn{3}{|c|}{ 95\% Confidence Intervals } \\
\hline Roots & Species & Polluted areas & $\begin{array}{l}1 \\
2\end{array}$ & $\begin{array}{l}1 \\
3\end{array}$ & $\begin{array}{l}2 \\
3\end{array}$ \\
\hline $\log (\mathrm{Cr})$ & 0.290 & $<0.001$ & $(-1.195,0.646)$ & $(-0.967,0.874)$ & $(-0.589,1.045)$ \\
\hline $\log (\mathrm{Pb})$ & 0.024 & 0.587 & $(-1.2214,0.0835)$ & $(-0.5877,0.7172)$ & $(0.0546,1.2128)^{*}$ \\
\hline $\log (\mathrm{Zn})$ & $<0.001$ & 0.001 & $(-0.6252,0.0208)$ & $(-0.0380,0.6080)$ & $(0.3004,0.8739)^{*}$ \\
\hline $\log (\mathrm{Cu})$ & 0.129 & $<0.001$ & $(-0.2446,0.1634)$ & $(-0.1093,0.2986)$ & $(-0.0458,0.3163)$ \\
\hline \multicolumn{6}{|l|}{ Aboveground } \\
\hline As & 0.494 & $<0.001$ & $(-0.0983,0.0617)$ & $(-0.1150,0.0450)$ & $(-0.0893,0.0559)$ \\
\hline $\log (Z n)$ & 0.183 & 0.014 & $(-0.220,0.601)$ & $(-0.108,0.704)$ & $(-0.266,0.481)$ \\
\hline $\log (\mathrm{Cr})$ & 0.538 & $<0.001$ & $(-0.971,0.792)$ & $(-0.842,0.903)$ & $(-0.682,0.922)$ \\
\hline \multicolumn{6}{|l|}{ Inflorescence } \\
\hline $\log (\mathrm{As})$ & 0.089 & $<0.001$ & $(-0.2329,0.2863)$ & $(-0.3646,0.1547)$ & $(-0.3708,0.1075)$ \\
\hline $\log (\mathrm{Pb})$ & 0.366 & $<0.001$ & $(-0.4308,0.5499)$ & $(-0.6415,0.3498)$ & $(-0.6562,0.2454)$ \\
\hline $\log (\mathrm{Zn})$ & 0.003 & $<0.001$ & $(-0.2514,0.3011)$ & $(-0.578,-0.020)^{*}$ & $(-0.578,-0.070)^{*}$ \\
\hline $\log (\mathrm{P})$ & 0.007 & $<0.001$ & $(-583.6,537.1)$ & $(-1109.8,230.0)$ & $(-1035.3,-5.0)^{*}$ \\
\hline
\end{tabular}

Bold - p-values indicate significant differences $(\mathrm{p}<0.05),{ }^{*}$ indicates significant differences between species.

Bothe [49] presents details about the mechanisms used by plants to tolerate metals, while providing a vast literature. As it is known $[45,49]$ in general, and also in our studies, roots have a higher metal content than the aboveground part of plants, which can be seen in Tables 8, and 9 . It was also found that in area A, elements such As, Cr, Mn, and $\mathrm{Ni}$ presented higher concentrations in all three plant parts as compared to area B (Tables 8 and 9). However, when working with soils there is an obvious risk that microscopical soil particles may adhere to the root surface and there is also a high probability of finding nanoparticles of biominerals on the root surface, too. These particles are extremely difficult to remove from the root, and if they contain any pollutant metals they will be considered part of the root biomass.

In the case of clover and plantain, Mn concentrations were even higher in their inflorescence in area $\mathrm{B}$ as a result of increased mobility probably due to decreased $\mathrm{pH}$. This is confirmed in the case of the dandelion, for which $\mathrm{pH}$ had almost similar values. In this case, the Mn concentration did not increase in the plants collected from area B. It was actually lower in all three plant parts as a consequence of concentration alleviation in soil. We mentioned that both $\mathrm{Cr}$ and $\mathrm{Ni}$ registered excessive or toxic values $\left(>0.1-0.5 \mu \mathrm{g} \cdot \mathrm{g}^{-1} \mathrm{Cr}\right.$ and $>0.5-1 \mu \mathrm{g} \cdot \mathrm{g}^{-1} \mathrm{Ni}$ according to Kabata-Pendias and Pendias [31]) in almost all plant parts for both areas. The other elements presented here did not exceed the acceptable level in plants. Moreover, as we can see in Tables 8 and 9, the content of both $\mathrm{P}$ and toxic elements in plant parts was significantly different in the two polluted areas. In inflorescence, there were differences between areas A and B for all elements. In roots, there seemed to be no evidence of a difference for $\mathrm{Mn}$ and $\mathrm{Pb}$ between areas, whereas in the aboveground parts there was no evidence of a difference in the $\mathrm{Mn}$ content between the two areas. In general, there is no correlation between the soil metal content and the plant [50]. In the case of our studies, the plots from Fig. 1 also show that not all elements and pseudo-total concentrations of $\mathrm{P}$ in soil are correlated with the concentrations found in the three parts of the plants (roots, aboveground, and inflorescence) from the A and B areas. Also, the diagrams from Fig. 2 show the distribution of toxic elements and $\mathrm{P}$ in plant parts and soil. This was done by considering each polluted area separately, in order to spot the differences between the two areas. Thus it could be observed that the As, Cr, Mn, and $\mathrm{Ni}$ content in soil was higher in area A than in area B. The higher concentrations in the case of the clover and the plantain in area A could also be caused by the fact that the $\mathrm{pH}$ in the rhizospheres was higher, and it is known that neutral $\mathrm{pH}$ increases As solubilization and the potential bioaccumulation of this element in the food chain, depending of course, of their speciation which exist in soils [31, 51]. Similar patterns of variation to those shown in Figs. 1 and 2 were found in the case of element concentration in bioavailable form (data not shown).

\section{Oxidative Stress}

It is documented that in the environments where concentrations of toxic metals are over the accepted limit, if the enzymatic and non-enzymatic activities in plants increase, they can better tolerate the stress induced by metals [52]. 
Matrix Plot of As_soil vs As_roots, As_aboveground, As_flowers

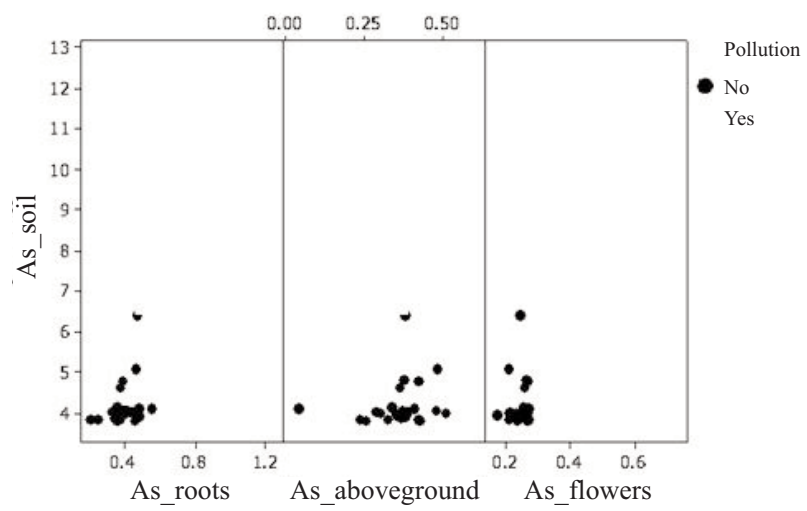

Matrix Plot of $\mathrm{Cu}$ _soil vs $\mathrm{Cu}$ _roots, $\mathrm{Cu}$ _aboveground, $\mathrm{Cu}$ _flowers

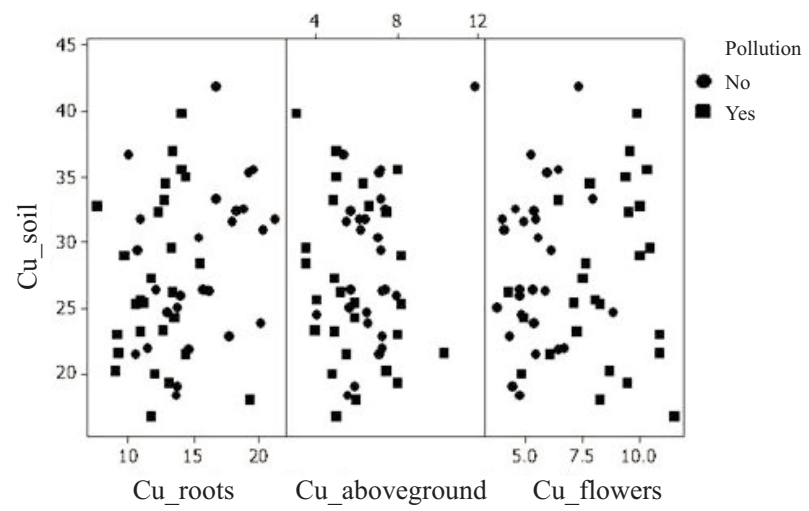

Matrix Plot of Ni_soil vs Ni_roots, $\mathrm{Ni}$ _aboveground, $\mathrm{Ni}$ _flowers

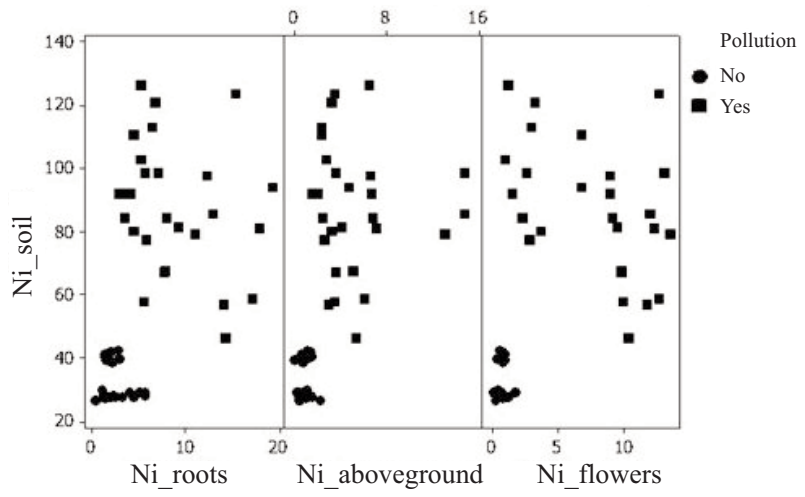

Matrix Plot of $\mathrm{P}_{-} \mathrm{PO}_{4}$ vs $\mathrm{P}$ _roots, $\mathrm{P}$ _aboveground, $\mathrm{P}$ _flowers

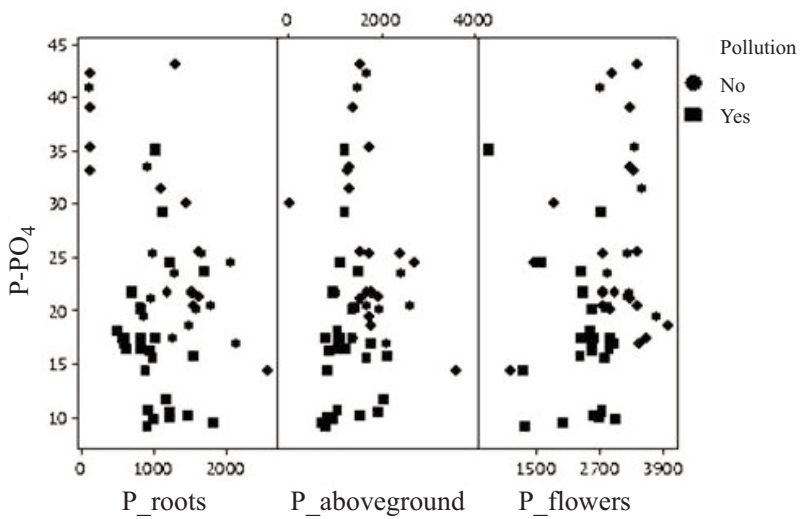

Matrix Plot of Zn_soil vs Zn_roots, Zn_aboveground, Zn_flowers

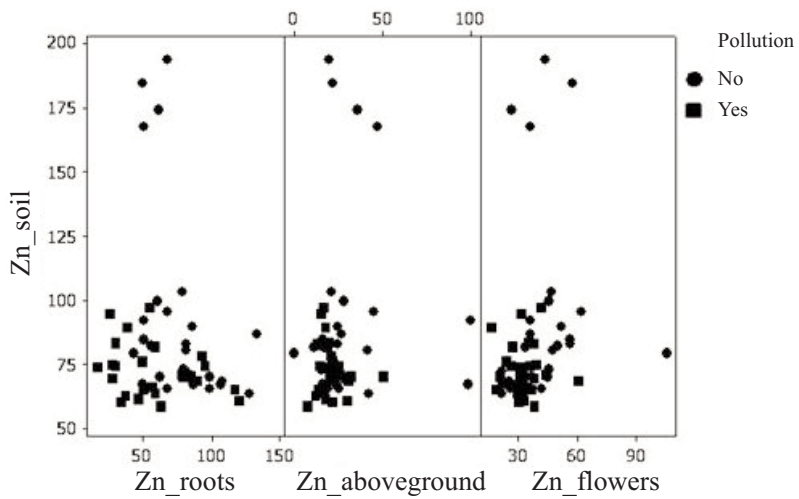

Matrix Plot of Cr_soil vs Cr_roots, $\mathrm{Cr}$ _aboveground, $\mathrm{Cr}$ _flowers

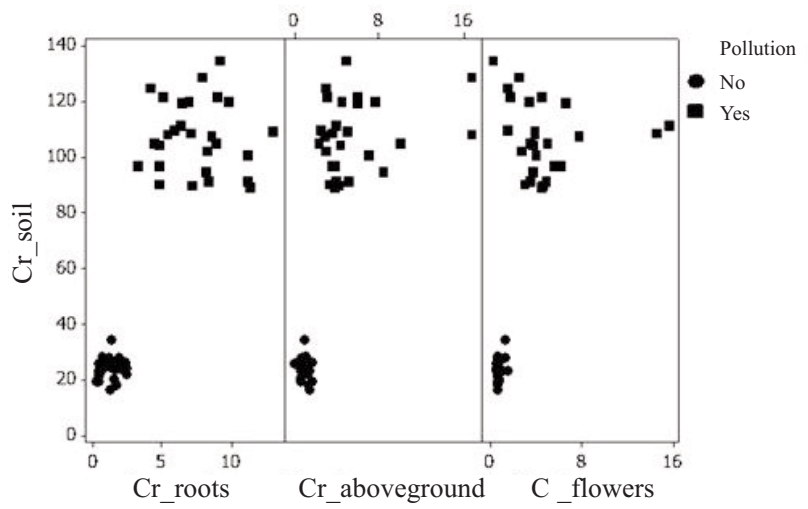

Matrix Plot of Mn_soil vs Mn_roots, Mn_aboveground, Mn_flowers

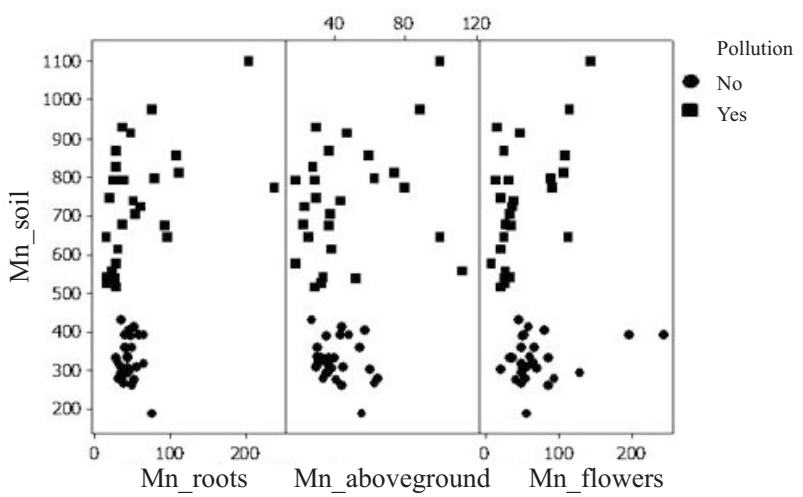

Matrix Plot of $\mathrm{Pb} \_$soil vs $\mathrm{Pb}$ _roots, $\mathrm{Pb}$ _aboveground, $\mathrm{Pb}$ flowers

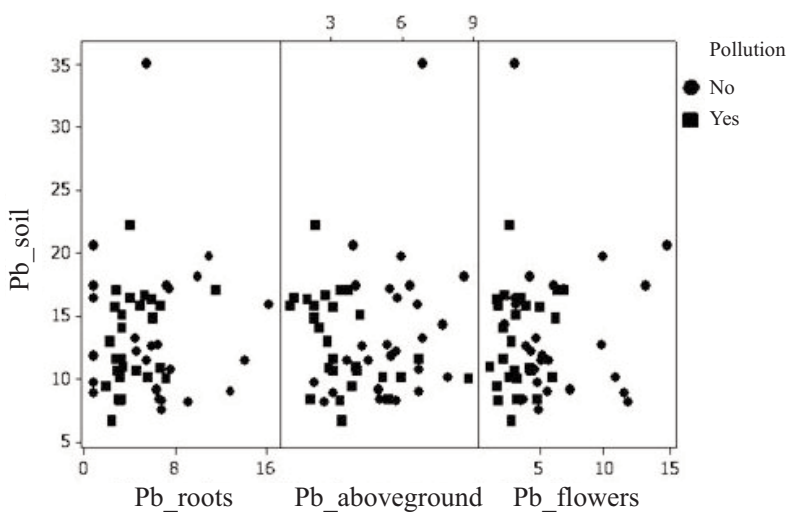

Fig. 1. Correlations between the concentrations of heavy metals and $\mathrm{P}$ in soil and plant parts. 
Histogram of As_roots, As_aboveground, As_flowers, As_soil

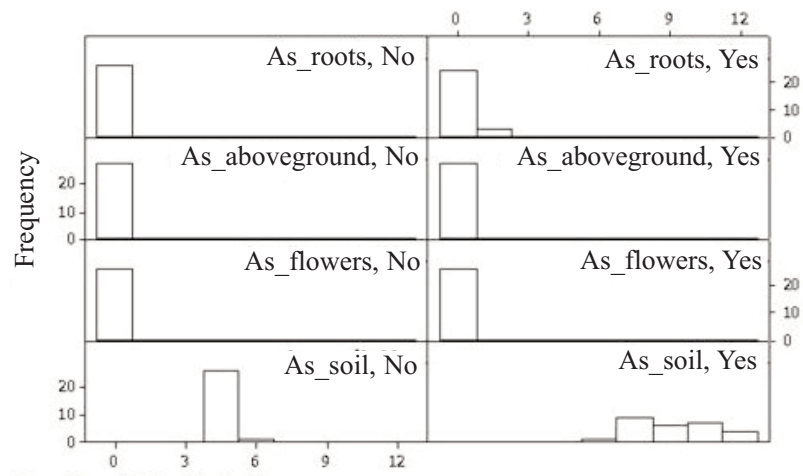

Panel variable: Pollution

Histogram of $\mathrm{Cu}$ _roots, $\mathrm{Cu}$ _aboveground, $\mathrm{Cu}$ _flowers, $\mathrm{Cu}$ _soil

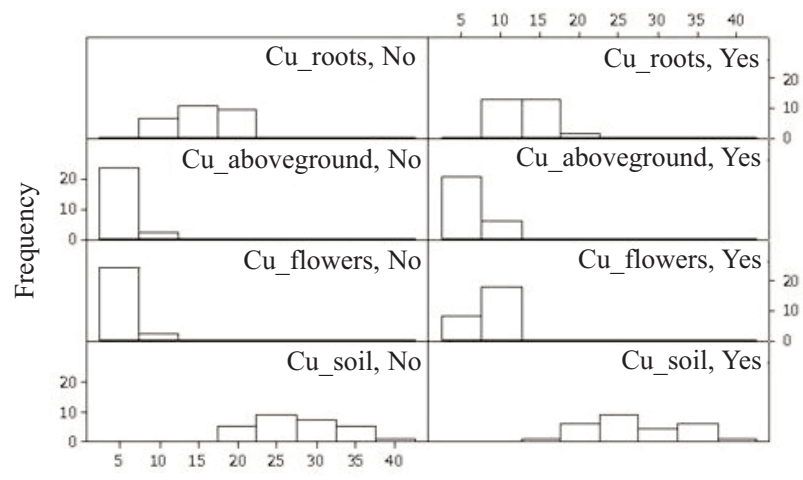

Panel variable: Pollution

Histogram of Ni_roots, $\mathrm{Ni}$ _aboveground, $\mathrm{Ni}$ _flowers, $\mathrm{Ni}$ _soil

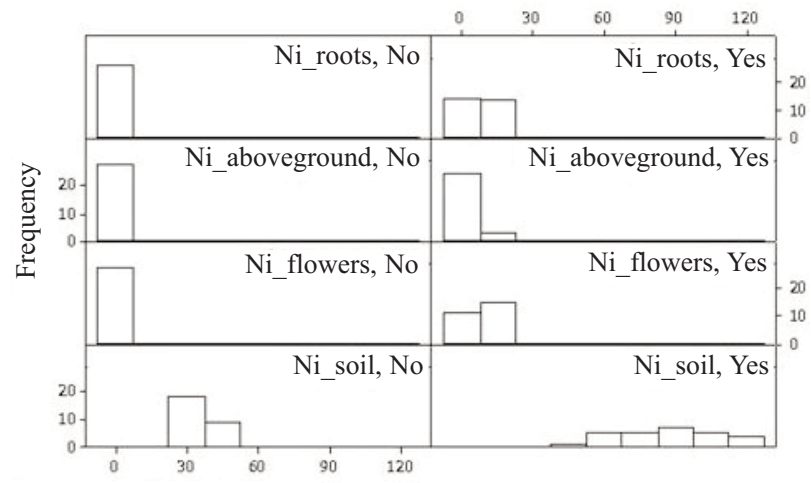

Panel variable: Pollution

Histogram of $\mathrm{P}$ _roots, $\mathrm{P}$ _aboveground, $\mathrm{P}$ _flowers, $\mathrm{P}_{-} \mathrm{PO}_{4}$

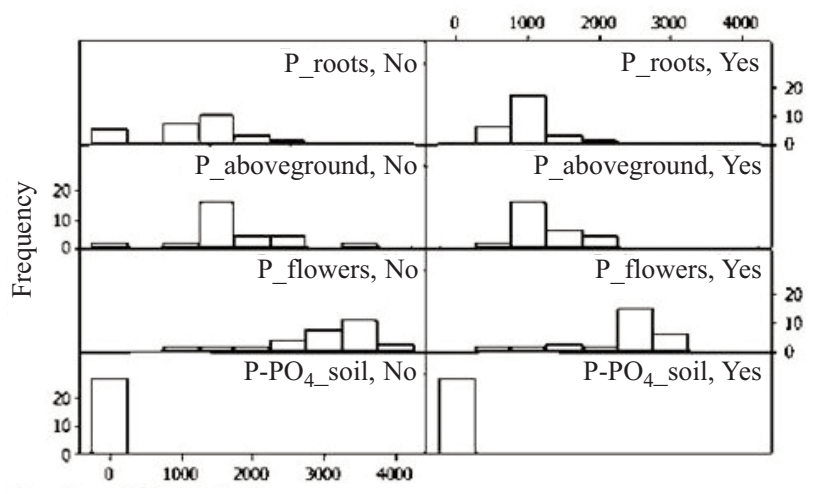

Panel variable: Pollution
Histogram of $\mathrm{Cr}$ _roots, $\mathrm{Cr}$ _aboveground, $\mathrm{Cr}$ _flowers, $\mathrm{Cr}$ _soil

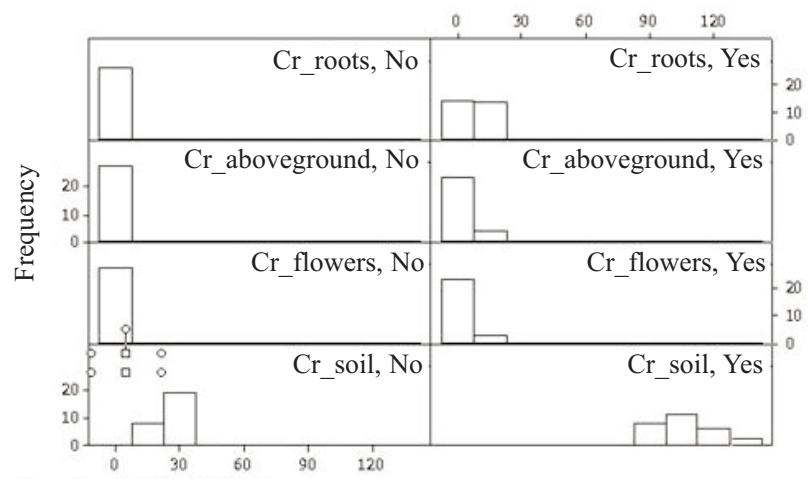

Panel variable: Pollution

Histogram of Mn_roots, Mn_aboveground, Mn_flowers, Mn_soil

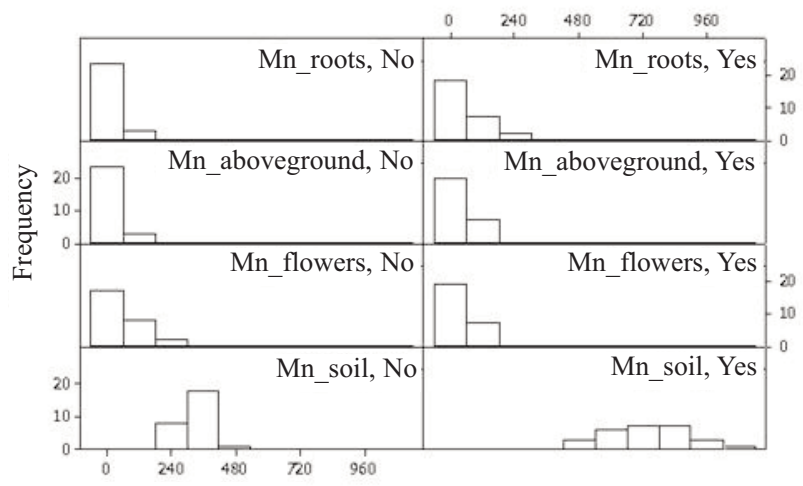

Panel variable: Pollution

Histogram of $\mathrm{Pb}$ _roots, $\mathrm{Pb}$ _aboveground, $\mathrm{Pb}$ _flowers, $\mathrm{Pb}$ _soil

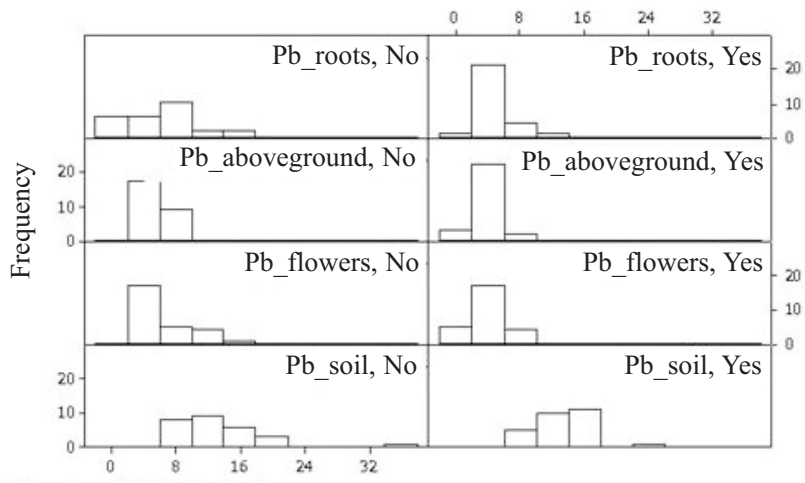

Panel variable: Pollution

Histogram of $\mathrm{Zn \_ roots,} \mathrm{Zn \_ aboveground,} \mathrm{Zn \_ flowers,} \mathrm{Zn \_ soil}$

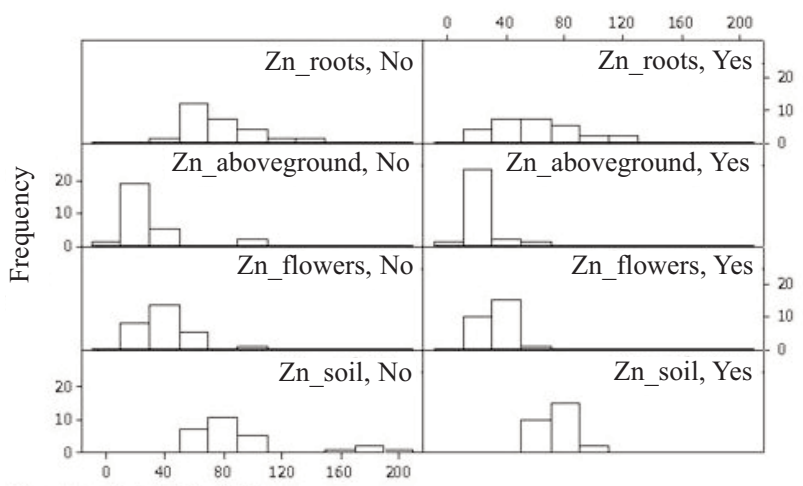

Panel variable: Pollution

Fig. 2. Histograms showing the distribution of heavy metals and $\mathrm{P}$ in plant parts and soil in the polluted area. 
Table 10. Biochemical variables of the three species of plants.

\begin{tabular}{|c|c|c|c|c|c|c|c|c|}
\hline Area & $\begin{array}{l}\text { Roots } \\
\text { d.w. }\end{array}$ & $\begin{array}{l}\text { Proteins } \\
\mathrm{mg} \cdot \mathrm{g}^{-1}\end{array}$ & $\begin{array}{c}\text { SOD } \\
\mathrm{mU} \cdot \mathrm{mg}^{-1} \text { prot. }\end{array}$ & $\begin{array}{c}\text { POD } \\
\mu \mathrm{U} \cdot \mathrm{mg}^{-1} \cdot \text { prot. }\end{array}$ & $\begin{array}{l}\mathrm{Chl} a \\
\mathrm{mg} \cdot \mathrm{g}^{-1}\end{array}$ & $\begin{array}{l}\mathrm{Chl} b \\
\mathrm{mg} \cdot \mathrm{g}^{-1}\end{array}$ & $\begin{array}{l}\text { Carotenoids } \\
\mathrm{mg} \cdot \mathrm{g}^{-1}\end{array}$ & $\begin{array}{c}\mathrm{LP} \mu \mathrm{M} \\
\text { MDA.g-1 }\end{array}$ \\
\hline \multirow{3}{*}{ A } & Dandelion & $1.788 \pm 0.319$ & $9.809 \pm 1.839$ & $2.235 \pm 0.418$ & na & na & na & $17.45 \pm 7.041$ \\
\hline & Clover & $2.057 \pm 0.300$ & $13.60 \pm 2.650$ & $3.745 \pm 0.999$ & na & na & na & $22.03 \pm 3.744$ \\
\hline & Plantain & $1.616 \pm 0.067$ & $15.04 \pm 3.475$ & $2.015 \pm 0.359$ & na & na & na & BDL \\
\hline \multirow{3}{*}{ B } & Dandelion & $32.87 \pm 8.449$ & $0.769 \pm 0.187$ & $0.020 \pm 0.013$ & na & na & na & $0.215 \pm 0.047$ \\
\hline & Clover & $33.30 \pm 13.39$ & $0.892 \pm 0.328$ & $0.029 \pm 0.013$ & na & na & na & $0.318 \pm 0.089$ \\
\hline & Plantain & $28.56 \pm 3.068$ & $0.963 \pm 0.228$ & $0.039 \pm 0.009$ & na & na & na & BDL \\
\hline Area & $\begin{array}{l}\text { Aboveground } \\
\text { d.w. }\end{array}$ & $\begin{array}{l}\text { Proteins } \\
\mathrm{mg} \cdot \mathrm{g}^{-1}\end{array}$ & $\begin{array}{c}\text { SOD } \\
\mathrm{mU} \cdot \mathrm{mg}^{-1} \cdot \text { prot. }^{-}\end{array}$ & $\begin{array}{c}\text { POD } \\
\mu \mathrm{U} \cdot \mathrm{mg}^{-1} \cdot \text { prot. }\end{array}$ & $\begin{array}{l}\mathrm{Chl} a \\
\mathrm{mg} \cdot \mathrm{g}^{-1}\end{array}$ & $\begin{array}{l}\mathrm{Chl} b \\
\mathrm{mg} \cdot \mathrm{g}^{-1}\end{array}$ & $\begin{array}{l}\text { Carotenoids } \\
\mathrm{mg} \cdot \mathrm{g}^{-1}\end{array}$ & $\begin{array}{c}\mathrm{LP} \mu \mathrm{M} \\
\mathrm{MDA} \cdot \mathrm{g}^{-1}\end{array}$ \\
\hline \multirow{3}{*}{ A } & Dandelion & $5.138 \pm 9.350$ & $3.276 \pm 0.413$ & $0.563 \pm 0.098$ & $1.329 \pm 0.248$ & $0.470 \pm 0.092$ & $0.071 \pm 0.010$ & $15.26 \pm 2.271$ \\
\hline & Clover & $6.096 \pm 0.496$ & $3.516 \pm 0.996$ & $0.577 \pm 0.124$ & $2.747 \pm 0.941$ & $0.938 \pm 0.295$ & $0.144 \pm 0.046$ & $18.61 \pm 2.717$ \\
\hline & Plantain & $2.184 \pm 0.139$ & $2.840 \pm 0.703$ & $1.166 \pm 0.306$ & $1.419 \pm 0.463$ & $0.620 \pm 0.176$ & $0.087 \pm 0.023$ & BDL \\
\hline \multirow{3}{*}{ B } & Dandelion & $33.05 \pm 3.785$ & $0.576 \pm 0.094$ & $0.018 \pm 0.009$ & $1.043 \pm 0.274$ & $0.347 \pm 0.087$ & $0.064 \pm 0.016$ & $0.245 \pm 0.034$ \\
\hline & Clover & $26.76 \pm 5.278$ & $0.733 \pm 0.038$ & $0.019 \pm 0.008$ & $2.612 \pm 0.478$ & $0.797 \pm 0.140$ & $0.132 \pm 0.016$ & $0.283 \pm 0.113$ \\
\hline & Plantain & $27.71 \pm 3.731$ & $0.733 \pm 0.204$ & $0.034 \pm 0.007$ & $0.648 \pm 0.084$ & $0.215 \pm 0.033$ & $0.050 \pm 0.005$ & BDL \\
\hline Area & $\begin{array}{c}\text { Inflorescence } \\
\text { d.w. }\end{array}$ & $\begin{array}{l}\text { Proteins } \\
\mathrm{mg} \cdot \mathrm{g}^{-1}\end{array}$ & $\begin{array}{c}\text { SOD } \\
\mathrm{mU} \cdot \mathrm{mg}^{-1} \text { prot. }\end{array}$ & $\begin{array}{c}\text { POD } \\
\mu \mathrm{U} \cdot \mathrm{mg}^{-1} \cdot \text { prot. }\end{array}$ & $\begin{array}{l}\mathrm{Chl} a \\
\mathrm{mg} \cdot \mathrm{g}^{-1}\end{array}$ & $\begin{array}{l}\mathrm{Chl} b \\
\mathrm{mg} \cdot \mathrm{g}^{-1}\end{array}$ & $\begin{array}{c}\text { Carotenoids } \\
\mathrm{mg} \cdot \mathrm{g}^{-1}\end{array}$ & $\begin{array}{c}\mathrm{LP} \mu \mathrm{M} \\
\mathrm{MDA} \cdot \mathrm{g}^{-1}\end{array}$ \\
\hline \multirow{3}{*}{ A } & Dandelion & $0.881 \pm 213.9$ & $7.554 \pm 2.657$ & $1.446 \pm 0.522$ & na & na & na & $21.37 \pm 6.240$ \\
\hline & Clover & $1.180 \pm 0.153$ & $1.513 \pm 0.663$ & $1.236 \pm 0.243$ & na & na & na & $59.82 \pm 3.351$ \\
\hline & Plantain & $0.578 \pm 0.163$ & $10.98 \pm 9.263$ & $2.754 \pm 7.358$ & na & na & na & $\mathrm{BDL}$ \\
\hline \multirow{3}{*}{ B } & Dandelion & $34.46 \pm 3.928$ & $0.526 \pm 0.148$ & $0.017 \pm 0.009$ & na & na & na & $0.247 \pm 0.030$ \\
\hline & Clover & $32.48 \pm 8.816$ & $0.507 \pm 0.151$ & $0.013 \pm 0.005$ & na & na & na & $0.795 \pm 0.074$ \\
\hline & Plantain & $32.48 \pm 8.761$ & $0.614 \pm 0.167$ & $0.023 \pm 0.006$ & na & na & na & $\mathrm{BDL}$ \\
\hline
\end{tabular}

na - not analyzed (not relevant for the part of plant), BDL - below detection limit $(<0.02 \mu \mathrm{M}$ MDA)

Antioxidants and antioxidative enzymes such as superoxide dismutases (SOD), catalases (CAT), and peroxidases (POD) function by interrupting the negative effect of the ROS. Plants produce several forms of SOD, which contain $\mathrm{Cu}, \mathrm{Zn}, \mathrm{Fe}$, and $\mathrm{Mn}$ in their active centers. Thus, when bigger quantities of metals such as $\mathrm{Ni}, \mathrm{Zn}$, and $\mathrm{Mn}$ are added, the SOD activities increase with up to $20 \%$ more than the means obtained on the control area [53].

In our studies we also assessed the SOD and POD activities, and implicitly, the protein content in the investigated plant species. The values of these activities for all three species of plants grown in areas A and B can be seen in Table 10. Moreover, it could be observed that when the pollution was stronger (area A), the protein content significantly decreased in all three plant parts $(\mathrm{p}<0.05)$. This protein content consequently led to an increase in enzymatic activities, and so the SOD activity was more intense in the roots, followed by inflorescence and then the aboveground part of plants. The same variation pattern was noticed for POD activities, too. A similar increase in SOD activities also was found by Guala et al. [53] in their research (up to $60 \%$ compared to the control area) when mixtures of $\mathrm{Ni}+\mathrm{Cd}$,
$\mathrm{Ni}+\mathrm{Zn}$, and $\mathrm{Ni}+\mathrm{Mn}$ were added. Mehes-Smith et al. [52] stated that metal toxicity decreased the level of SOD and ascorbate peroxidase (APX), but increased the activity of catalase (CAT) and glutathione reductase (GR), while Dazy et al. [8] reported an increase in SOD and CAT activities for all investigated species, but working only on leaves on strong gradients of soil metal pollution. For the biochemical variables, statistically significant differences were registered between the pollution areas A and B in most parts of the three species of plants. The content of proteins, SOD, and $\mathrm{POD}$ in roots and inflorescence was statistically different between areas. Also, in the aboveground part the content of proteins, SOD, POD, carotenoids, chl a, and chl b were statistically different between areas. We also remarked that there were differences between species, as indicated by $\mathrm{p}$-values $(\mathrm{p}<0.05)$ and 95\% Confidence Intervals (when they do not include zero). These differences were similar to the ones found when comparing the areas, except for the content of SOD in the aboveground part, which was not statistically different between species. A statistical analysis on LP could not be performed as this was below the detection limit $(<0.02 \mu \mathrm{M}$ MDA $)$ for the plantain species. 
The statistical increase of $\mathrm{P}$ in plants is correlated with a higher content of protein and a lower enzymatic (SOD and POD) activity. Neagoe et al. [54] found similar positive correlations between protein and $\mathrm{P}$ nutrition in the case of four plant species grown on a metal-contaminated soil. Also, in a recent study, $[55,56]$ it was shown that P nutrition strongly influenced the development of Agrostis capillaris on a mine tailing substrate, alleviating the oxidative stress and increasing the protein content. We found the same variation pattern in the case of the enzymatic activities, but not in the case of lipid peroxides in plantain, whose concentration was below the detection limit of the used method (Table 10). Another measured biochemical variable was the content of photosynthetic pigments assessed in the aboveground part of plants. Surprisingly, both chlorophyll $a$ and $b$ and the carotenoids content registered slightly higher values in area A than in the less polluted area B. SánchezViveros et al. [57] proved that when a concentration of metals was present, both the chlorophyll and the carotenoids contents were affected.

These findings could be partially explained through the negative impact of the metals on the perturbation of photosystem II. Moreover, Maleva et al. [14] observed a slight decrease of the chlorophyll contents after applying a combined treatment of $\mathrm{Mn}$ and $\mathrm{Zn}$ on Elodea (Egeria) densa, whereas when $\mathrm{Cd}$ was added, the chlorophyll contents slowly increased (by up to $9 \%$ compared to the control area). The same authors demonstrated the decrease (up to $1.5 \%$ ) of the carotenoids content after adding $\mathrm{Cu}$ separately or combined with Mn and the increase (up to 24\%) of their content when $\mathrm{Cd}$ was added. The stimulation of the carotenoids as a result of heavy metal pollution was also noticed by Mascher et al. [58], who stated that this effect could be attributed to a defense mechanism against the oxidative stress induced by the presence of high heavy metal concentrations. In addition, Kanoun-Boulé and Vicente [59] stated that the inhibitive or stimulating effects of metals on photosynthetic pigments content could be the result of sensitivity or tolerance particular to each species of plant. In our case, the polymetallic pollution had a clear effect of stimulating the photosynthetic pigments when there was a higher heavy metal concentration in area A.

It can be concluded that the physiology of plants has a great influence on their response to the stress induced by the presence of toxic elements. Even if the plants were sampled during the same vegetation period but in areas with different degrees of pollution (A and B), they had different growth conditions, which were influenced by temperature, different levels of humidity, shadowing, different nutrients content, etc. Neagoe et al. [54] reported that the P content in plants is a decisive factor in diminishing the oxidative stress caused by the presence of metals. There were statistically significant differences between the $\mathrm{P}$ concentration in area $\mathrm{A}$ and the $\mathrm{P}$ concentration in area $\mathrm{B}$, as indicated by the statistical analysis carried out (Tables 8 and 9). The plants in area A showed, on average, lower P concentrations in the entire plant (all three species and parts of plant) as compared to area B (Table 7). It must be men- tioned that $\mathrm{P}$ registered a value below the recommended limit in area $\mathrm{A}$, whereas the concentrations in area $\mathrm{B}$ were within the sufficiency interval of $2000-5000 \mu \mathrm{g} \cdot \mathrm{g}^{-1} \mathrm{P}$, according to Marschner [60].

Following the results obtained in terms of biochemical variables of three species and three plant parts grown in two areas with different levels of pollution, we support the idea that after more extensive investigation, these variables could be included in the monitoring program. By using these biochemical variables as bioindicators, the early detection of changes in the structure and function of biological systems could be possible as we believe that a timely reaction of the governments would prevent the irreversible damaging of the ecosystems. The advantage of using such bioindicators instead of instrument monitoring lies in the fact that they have the capacity to offer a response to the combined effect of various pollutants as is the case with our research area, where polymetallic pollution exists.

\section{Conclusions}

The three species of plants responded to the changes in soil pollution with toxic elements in a similar way, recording an increase of protein concentrations in all species and plant parts coupled with a decrease of SOD and POD activity. Moreover, the polymetallic pollution had a clear effect of stimulating the photosynthetic pigments when there was a higher concentration of both pseudo-total and bioavailable forms of elements with toxic potential. However, these results were inferred by changes in phosphorus availability in soil. The three plant species which have been investigated have been shown to be good bio-indicators of oxidative stress, but to support the idea that they may be used as a tool for early warning detection of alterations in metabolism, it is necessary to continue research on a greater number of plants and on the most varied areas of pollution gradients. It is desired that a permanent monitoring be established in the future, with a focus on the integrated effects of the multiple stressors, including the oxidative stress variables. These stressors could help to make a timely identification of potential alterations in plant metabolism without destroying the crops or the pastures. Even more so, it is necessary that the climate changes be taken into consideration both seasonally and all year round, since seasonal sampling is not sufficient to assess the level of pollution. Before making recommendations on the use of plant biochemical variables in monitoring, it is essential to clarify how the available major nutrients $(\mathrm{N}, \mathrm{P})$ modulate the bioaccumulation of toxic elements and the effects they might have on plant biochemical variables, in particular on oxidative stress.

\section{Acknowledgements}

Field and laboratory activities were performed by means of the PN2 50/2012 ASPABIR partnership project funded by the Executive Agency for Higher Education, 
Research, Development, and Innovation Funding, Romania (UEFISCDI), and data processing and interpretation were done within the PN2 98/2014 TIMMAR partnership project funded by the same Romanian Executive Agency.

We thank Valeria Badea for proofreading and editing the English version of the manuscript, Roxana Donciu for help with the lab work, and the anonymous reviewers for their constructive criticism and helpful observations that greatly contributed to improving the final version of this paper.

\section{References}

1. MALEVA M.G., NEKRASOVA G.F., BORISOVA G.G., CHUKINA N.V., USHAKOVA O.S. Effect of heavy metals on photosynthetic apparatus and antioxidant status of Elodea. Russ. J. Plant Physiol. 59, (2), 190, 2012.

2. XIANCAN Z., FENGBIN S., HONGWEN X. Influence of arbuscular mycorrhiza on lipid peroxidation and antioxidant enzyme activity of maize plants under temperature stress. Mycorrhiza 20, 325, 2010.

3. JALEEL C.A., RIADH K., GOPI R., MANIVANNAN P., INÉS J., AL-JUBURI H.J., CHANG-XING Z., HONG-BO S., PANNEERSELVAM R. Antioxidant defense responses: physiological plasticity in higher plants under abiotic constraints. Acta Physiol. Plant 31, 427, 2009.

4. KHALVATI M., BARTHA B., DUPIGNY A., SCHRÖDER P. Arbuscular mycorrhizal association is beneficial for growth and detoxification of xenobiotics of barley under drought stress. J. Soils Sediments 10, 54, 2010.

5. GASSIC C., KORBAN S. Heavy metal stress. In: Matkawa Rao K.W., Raghawedra A.S., Janardhan R. (Eds). Plant Physiology and Molecular Biology of Stress Tolerance, Springer-Verlag, pp. 219-225, 2005.

6. SINGH J., KALAMDHAD A.S. International Journal of Environmental Engineering Research 2, (2), 27, 2013

7. ARZANESH M., ALIKHANI H., KHAVAZI K., RAHIMIAN H., MIRANSARI M. Wheat (Triticum aestivum L.) growth enhancement by Azospirillum sp. under drought stress. World J. Microbiol. and Biotechnol. 27, 197, 2011.

8. DAZY M., BÉRAUD E., COTELLE S., GRÉVILLIOT F., FÉRARD J.F., MASFARAUD J.F. Changes in plant communities along soil pollution gradients: Responses of leaf antioxidant enzyme activities and phytochelatin contents. Chemosphere 77, 376, 2009.

9. AL SAYEGH PETKOVŠEK S. Forest biomonitoring of the largest Slovene thermal power plant with respect to reduction of air pollution. Environ. Monit. Assess. 185, 1809, 2013.

10. CSEREKLYE E.K. Monitoring of landscape combinations and concourses in the Hungarian Danube-bend. J. Environ. Eng. Landscape Manag. 18, 1, 2010.

11. LIGOCKI M., TARASEWICZ Z., ZYGMUNT A., ANIŚKO M. The common dandelion (Taraxacum Officinale) as an indicator of anthropogenic toxic metal pollution of environment. Acta Sci. Pol. Zootechnica 10, (4), 73, 2011.

12. MARTINESCU D.M., CĂPUŞNEANU S. Environment and environmental effects of pollution. Model of eco-dashboard - A tool for analysis of environmental management performances. Metalurgia International 14, (12), 113, 2010. http://mpra.ub.uni-muenchen.de/26923/.

13. NOTCUTT G., DAVIES F. Environmental accumulation of airborne fluorides in Romania. Environ. Geoch. Hlth. 23, 43, 2001.
14. CHEVERESAN M.I., MINCIUNĂ M.N., DROBOT R. Spatial data infrastructure for groundwater integrated management with application in three case studies in Romania. WSEAS Transactions Environ. Develop. 11, (5), 673, 2009.

15. FAO-UNESCO. Soil Map of the World, 9 volumes. UNESCO, Paris, France, 1974.

16. UNDP PROJECT ROM 98/012. Local agenda 21 - Local Plan for Sustainable Development of Slatina Municipality. Tradition and Development, pp. 95, 2004. www.undp.ro/projects.php (Romanian language)

17. HOFFMANN G. Book of Methods, Volume 1, The analysis of soils, VDLUFA Publishing House, Darmstadt, 1991.

18. ZEIEN H., BRÜMMER G.W. Chemical extraction for the determination of heavy metal binding forms in soil. German communication, Soil Science Society. 59, 505, 1989.

19. NEAGOE A., EBENA G., CARLSSON E. The effect of soil amendments on plant performance in an area affected by acid mine drainage. Chem. Erde-Geochem. 65, 115, 2005.

20. LOWRY O.H., ROSEBROUGH N.J., FARR A.L., RANDALL R.J. Protein measurement with the Folin phenol reagent. J. Biol. Chem. 193, 265, 1951.

21. MCCORD J.M., FRIDOVICH I. Superoxide dismutase: an enzymatic function for erythrocuprein. J. Biol. Chem. 244, 6049, 1969.

22. LAGRIMINI L.M. Wound-induced deposition of polyphenols in transgenic plants overexpressing peroxidase. Plant Physiol. 96, 577, 1991.

23. HODGES M.D., DELONG J.M., FORNEY C.F., PRAUGE R.K. Improving the thiobarbituric acid-reactive substances assay for estimating lipid peroxidation in plant tissues containing anthocyan and other interfering compounds. Planta 207, 607, 1999.

24. SCHOPFER P. Experimental plant physiology Introduction to the application. Volume 2, Springer Berlin, 1989.

25. UUSIPAIKKA E. Exact simultaneous Confidence Intervals for multiple comparisons among three or four mean values. J. Am. Stat. Assoc. 80, 196, 1985.

26. INRA. Reference Pedology, French Association of Soil Study, pp. 332, 1995.

27. GRIFFIN G., JOKELA W., ROSS D., PETTINELLI D., MORRIS T., WILF A. Recommended Soil Nitrate Tests. In: Northeastern Regional Publication (Ed.). Recommended Soil Testing Procedures for the Northeastern United States. Cooperative Bulletin No. 493, pp 27-38, 2009.

28. HOWARD A.E. Agronomic thresholds for soil phosphorus in Alberta: A review. In: Alberta Soil Phosphorus Limits Project. Volume 5: Background information and reviews. Alberta Agriculture, Food and Rural Development, Lethbridge, Alberta, Canada. Publishing: Irrigation Branch Alberta Agriculture, Food and Rural Development Lethbridge, Alberta, Canada, pp. 42, 2006.

29. ARSHAD M.A., MARTIN S. Identifying critical limits for soil quality indicators in agro-ecosystems. Agr. Ecosyst. Environ. 88, 153, 2002.

30. EFFROYMSON R.A., WILL M.E., SUTER G.W., WOOTEN A.C. Toxicological Benchmarks for Screening Contaminants of Potential Concern for Effects on Terrestrial Plants. Prepared for the U.S. Department of Energy, Office of Environmental Management, ES/ER/TM-85/R3, 1997.

31. KABATA-PENDIAS A., PENDIAS H. Trace elements in soils and plants, $3^{\text {rd }}(\mathrm{Ed}$.), CRC Press, Boca Raton, Florida, 2001. 
32. SENILA M. Real and simulated bioavailability of lead in contaminated and uncontaminated soils. Journal of Environmental Health Science \& Engineering 12, 108, 2014.

33. BECHERESCU D., DASCĂLU D., SUSINSKI M. The set up of the fertilizer doses in function of the agrochemical analyses with some field crops on a soil from Slatina Coteana, district Olt. Annals of the University of Craiova, Agr. Montan. Cadastre series 39, 320, 2009.

34. KATANA S.J.S., UCAKUWUN E.K., MUNYAO T.M. Detection and prediction of land cover changes in upper Athi River catchment, Kenya: A strategy towards monitoring environmental changes. Greener Journal of Environment Management and Public Safety 2, (4), 146, 2013.

35. 35. GUAN D., LIU Z., GENG Y., LINDNER S., HUBACEK K. The gigatonne gap in China's carbon dioxide inventories. Nature Climate Change 2, 672, 2012.

36. ZHENG G.D., CHEN T.B., GAO D., LUO W. Stabilization of nickel and chromium in sewage sludge during aerobic composting. J. Hazard. Mater. 142, 216, 2007.

37. MARTINEZ C.E., MOTTO H.L. Solubility of lead, zinc, and copper added to mineral soils. Environ. Pollut. 107, (1), $153,2000$.

38. GUPTA A.K., SINHA S. Phytoextraction capacity of the plants growing on tannery sludge dumping sites. Bioresource Technol. 98, 1788, 2007.

39. NEAGOE A., IORDACHE V., FARCASANU I. The Role of Organic Matter in the Mobility of Metals in Contaminated Sites in Soil Biology. Volume 31: Bio-Geo Interactions in Metal-Contaminated Soils. Kothe E., Varma A. (Eds), Springer-Verlag Berlin Heidelberg, pp. 423, 2012.

40. SMITH S.R. A critical review of the bioavailability and impacts of heavy metals in municipal solid waste composts compared to sewage sludge. Environment Internation. 35, $142,2009$.

41. SINGH J., KALAMDHAD A.S. Effects of heavy metals on soil, plants, human health and aquatic life. International Journal of Research Chemistry and Environment 1, (2), 15, 2011.

42. BIALOWIEC A., DAVIES L., ALBUQUERQUE A., RANDERSON P. Nitrogen removal from landfill leachate in constructed wetlands with reed and willow: Redox potential in the root zone. J. Environ. Manage. 97, 22, 2012.

43. REVATHI S., SUBHASHREE VENUGOPAL Physiological and biochemical mechanisms of heavy metal tolerance. Int. J. Environ. Sci. 3, (5), 1339, 2013.

44. APPENROTH K.J. Definition of "Heavy Metals" and Their Role in Biological Systems. In: Sherameti I., Varma A. (eds). Soil Heavy Metals, Soil Biology, Springer-Verlag Berlin Heidelberg, 19, 19, 2010.

45. MALIZIA D., GIULIANO A., ORTAGGI G., MASOTTI A. Common plants as alternative analytical tools to monitor heavy metals in soil. Chem. Cent. J. 6, (2), S6, 2012. http://journal.chemistrycentral.com/content/6/S2/S6

46. SYTAR O., KUMAR A., LATOWSKI D., KUCZYNSKA P., STRZAŁKA K., PRASAD M.N.V. Heavy metal-induced oxidative damage, defense reactions, and detoxification mechanisms in plants. Acta Physiol. Plant. 35, 985, 2013.
47. PAL R.S., AGRAWAL P.K., BHATT J.C. Molecular Approach towards the Understanding of Defensive Systems against Oxidative Stress in Plant: A Critical Review. Int. J. Pharm. Sci. Rev. Res. 22, (2), No. 24, 131, 2013.

48. MAESTRI E., MARMIROLI M. Genetic and molecular aspects of metal tolerance and hyperaccumulation. In: Gupta D.K. and Sandalio L.M. (Eds). Metal toxicity in plants: Perception, signaling and remediation. Springer-Verlag Berlin Heidelberg, pp 41-63, 2012.

49. BOTHE H. Plants in heavy metal soils. In: Sheramati I. and Varma A. (eds). Detoxification of heavy metals. Soil Biology 30. Springer-Verlag Berlin, pp. 35-57, 2012.

50. CLEMENS S. Toxic metal accumulation, responses to exposure and mechanisms of tolerance in plants. Biochimie 88, 1707, 2006.

51. ADRIANO D.C. Trace Elements in Terrestrial Environments. Biogeochemistry, Bioavailability and Risk of Metals, $2^{\text {nd }}$ ed.; Springer-Verlag New York Berlin Heidelberg, pp. 866, 2001.

52. MEHES-SMITH M., NKONGOLO K., CHOLEWA E. Coping Mechanisms of Plants to Metal Contaminated Soil. In: Environmental Change and Sustainability, INTECH, pp 53-90, 2013.

http://creativecommons.org/licenses/by/3.0http://dx.doi. org/10.5772/ 55124.

53. GUALA S., VEGA F.A., COVELO E.F. Modeling the plantsoil interaction in presence of heavy metal pollution and acidity variations. Environ. Monit. Assess. 185, 73, 2013.

54. NEAGOE A., IORDACHE V., BERGMANN H., KOTHE E. Pattern of variations of effects of arbuscular mycorrhizal fungi on plants grown in contaminated soil. J. Plant Nutr. Soil Sci. 176, 273, 2013.

55. NEAGOE A., STANCU P., NICOARĂ A., ONETE M., BODESCU F., GHEORGHE R., IORDACHE V. Effects of arbuscular mycorrhizal fungi on Agrostis capillaris grown on amended mine tailing substrate at pot, lysimeter and field plot scales. Environ. Sci. Pollut. Res. 2013.

56. NICOARĂ A., STANCU P., NEAGOE A., DE GIUDICI G., KOTHE E., IORDACHE V. Coupled pot and lysimeter experiments assessing plant performance in microbially assisted phytoremediation. Environ. Sci. Pollut. Res. DOI 10.1007/s11356-013-2489-9, 2013.

57. SÁNCHEZ-VIVEROS G., FERRERA-CERRATO R., ALARCÓN A. Short-term effects of arsenate-induced toxicity on growth, chlorophyll and carotenoid contents, and total content of phenolic compounds of Azolla filiculoides. Water Air Soil Pollut. 217, 455, 2011.

58. MASCHER R., LIPPMANN B., HOLZINGER S., BERGMANN H. Arsenate toxicity: effects on oxidative stress response molecules and enzymes in red clover plants. Plant Sci. 163, (5), 961, 2002.

59. KANOUN-BOULÉ M., VICENTE J.A.F. Ecophysiological tolerance of duckweeds exposed to copper. Aquat. Toxicol. 91, 1, 2009.

60. MARSCHNER H. Mineral Nutrition of Higher Plants, $2^{\text {nd }}$ ed.; Academic Press, London, pp. 889, 1995. 